\title{
The influence of traffic and wood combustion on the stable isotopic composition of carbon monoxide
}

\author{
M. Saurer, A. S. H. Prévôt, J. Dommen, J. Sandradewi, U. Baltensperger, and R. T. W. Siegwolf \\ Paul Scherrer Institut, 5232 Villigen PSI, Switzerland \\ Received: 27 August 2008 - Published in Atmos. Chem. Phys. Discuss.: 17 November 2008 \\ Revised: 26 February 2009 - Accepted: 7 May 2009 - Published: 15 May 2009
}

\begin{abstract}
Carbon monoxide in the atmosphere is originating from various combustion and oxidation processes. Recently, the proportion of $\mathrm{CO}$ resulting from the combustion of wood for domestic heating may have increased due to political measures promoting this renewable energy source. Here, we used the stable isotope composition of $\mathrm{CO}\left(\delta^{13} \mathrm{C}\right.$ and $\delta^{18} \mathrm{O}$ ) for the characterization of different $\mathrm{CO}$ sources in Switzerland, along with other indicators for traffic and wood combustion $\left(\mathrm{NO}_{\mathrm{x}}\right.$-concentration, aerosol light absorption at different wavelengths). We assessed diurnal variations of the isotopic composition of $\mathrm{CO}$ at 3 sites during winter: a village site dominated by domestic heating, a site close to a motorway and a rural site. The isotope ratios of wood combustion emissions were studied at a test facility, indicating significantly lower $\delta^{18} \mathrm{O}$ of $\mathrm{CO}$ from wood combustion compared to traffic emissions. At the village and the motorway site, we observed very pronounced diurnal $\delta^{18} \mathrm{O}$-variations of $\mathrm{CO}$ with an amplitude of up to $8 \%$. Solving the isotope mass balance equation for three distinct sources (wood combustion, traffic, clean background air) resulted in diurnal patterns consistent with other indicators for wood burning and traffic. The average night-time contribution of wood-burning to total CO was $70 \%$ at the village site, $49 \%$ at the motorway site and $29 \%$ at the rural site based on the isotope mass balance. The results, however, depend strongly on the pure source isotope values, which are not very well known. We therefore additionally applied a combined $\mathrm{CO} / \mathrm{NO}_{\mathrm{x}}$-isotope model for verification. Here, we separated the $\mathrm{CO}$ emissions into different sources based on distinct $\mathrm{CO} / \mathrm{NO}_{\mathrm{x}}$ emissions ratios for wood combustion and traffic, and inserted this information in the isotope mass balance equation. Accordingly, a highly significant agreement between measured and calculated $\delta^{18} \mathrm{O}$ values of $\mathrm{CO}$ was found $(r=0.67, p<0.001)$. While different
\end{abstract}

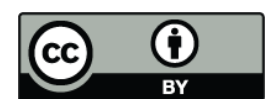

Correspondence to: M. Saurer (matthias.saurer@psi.ch) proxies for wood combustion all have their uncertainties, our results indicate that the oxygen isotope ratio of $\mathrm{CO}$ (but not the carbon isotope ratio) is an independent sensitive tool for source attribution studies.

\section{Introduction}

Carbon monoxide (CO) is an important trace gas of the atmosphere and widely studied due to its significant role in tropospheric chemistry (Crutzen and Zimmermann, 1991). In remote areas, $\mathrm{CO}$ is an important reactant of $\mathrm{OH}$ and thus influences the oxidation capacity of the troposphere. Also in polluted urban regions, $\mathrm{CO}$ is a significant $\mathrm{OH}$ sink (Dommen et al., 2002). However, CO reacts slower in the atmosphere compared to most other pollutants and can therefore be used as an overall indicator for the human activities related to emissions from combustion. When considering the isotope ratios of $\mathrm{CO}$, this approach can be extended for the partitioning of emissions into different sources. It was shown in studies in a rural area (Schauinsland, Germany) (Gros et al., 2002) as well as in a remote area (Spitzbergen) (Röckmann et al., 2002) that the oxygen isotope ratio of CO is useful for the characterization of exceptional pollution events. The relatively low oxygen isotope content of $\mathrm{CO}$ from wood combustion $\left(\delta^{18} \mathrm{O} \sim 16 \%\right.$ o $)$ compared to $\mathrm{CO}$ from car emissions $\left(\delta^{18} \mathrm{O} \sim 20-24 \%\right.$ o) enabled the detection of biomass burning events in these two studies. The method is not straightforward, however, because several source and sink effects have to be considered for explaining the $\delta^{18} \mathrm{O}$ of $\mathrm{CO}$ and because the signals of the emissions are not very well known and may be variable (Tsunogai et al., 2003). Regarding CO emission from cars, diesel exhausts can have a much lower oxygen isotope composition of about $11 \%$ compared to the isotope ratio of atmospheric $\mathrm{O}_{2}$ of $23.88 \%$ (Barkan and Luz, 2005), while even lower values down to $6 \%$ o have been observed for cold gasoline engines due to fractionation effects (Kato

Published by Copernicus Publications on behalf of the European Geosciences Union. 
et al., 1999b). While such differences can hamper an unambiguous source apportionment, it should be considered that a traffic mix of many cars should have a more well defined isotopic composition, determined, e.g., to be $20.7 \%$ $\pm 0.5 \%$ o for Mainz, Germany (Kato et al., 1999b). The main source of atmospheric $\mathrm{CO}$ besides the above-mentioned combustion processes is the oxidation of methane and non-methane hydrocarbons, which produces $\mathrm{CO}$ with a very low ${ }^{18} \mathrm{O}$ content (Gros et al., 2002). This effect is most important for aged air-masses and background air. On the other hand, the main sink effect, the reaction with $\mathrm{OH}$ to produce $\mathrm{CO}_{2}$, involves a large inverse isotope effect, where the heavier ${ }^{18} \mathrm{O}$ reacts more readily than ${ }^{16} \mathrm{O}$, resulting in a depletion of the remaining $\mathrm{C}^{18} \mathrm{O}$ in the atmosphere (Brenninkmeijer et al., 1999). Accordingly, a careful analysis of the isotope balance has to be made or additional tracers for constraining the isotope budget have to be measured, e.g. ${ }^{14} \mathrm{C}$ of $\mathrm{CO}$. Under conditions of heavy pollution, a simple two box-mixing model might be applicable by considering a source and background air (Kato et al., 1999a). Potentially, also $\delta^{13} \mathrm{C}$ of CO may provide additional source information. The carbon isotopic composition of $\mathrm{CO}$ from automobile exhaust is known to be close to the isotopic compositions of fuels used (Stevens et al., 1972), while isotope fractionations during biomass burning may result in deviations of the isotope ratio from the original material (Kato et al., 1999b).

Emissions from wood combustion are not only important on the global scale, but are also relevant in regional pollution studies. Although the energy consumption from wood heating amounts to only a few percent compared to fossil fuel combustion in Switzerland, the emissions of carbonaceous particles from wood burning are significant and were apparently underestimated in the past. Furthermore, policies fostering the use of renewable sources of energy may result in increased use of wood for heating purposes in the future. A recent study based on ${ }^{14} \mathrm{C}$ showed for an Alpine valley in winter that between $65 \%$ and $88 \%$ of carbonaceous matter of the ambient aerosol originate from non-fossil sources, most likely wood burning (Szidat et al., 2007). Also many VOC and OVOC concentrations are very strongly influenced by wood burning emissions (Gaeggeler et al., 2008). Besides traffic and industrial emissions, biomass burning contributes significantly to the organic aerosol mass even in a modern city like Zurich (Lanz et al., 2008; Szidat et al., 2006). During summer, forest and barbecue fires also result in a considerable fraction of the organic mass in urban areas (Lanz et al., 2007). A clear separation of the sources contributing to CO in the atmosphere could therefore further help in elucidating the role of wood combustion for the total pollution load.

In this study, we analysed ${ }^{13} \mathrm{C} /{ }^{12} \mathrm{C}$ and ${ }^{18} \mathrm{O} /{ }^{16} \mathrm{O}$ ratios of carbon monoxide at three sites, one influenced by domestic heating, one next to a motorway, and one at a rural location. The sampling was done at a high frequency $(30 \mathrm{~min}$ intervals) over several days, to provide insights into short-term variability and diurnal cycles, using an automated sampling and analysis system. Data at such high temporal resolution are practically non-existent in the literature. Additional analyses were done in a controlled setting where emissions from a $\log$ wood stove were assessed at a test facility. The study was conducted in the framework of a project where aerosol emissions from wood burning were analysed in great detail, in both laboratory and field studies (AEROWOOD, Aerosols from Wood burning versus other sources, Sandradewi et al., 2008b; Weimer et al., 2008; Alfarra et al., 2007; Szidat et al., 2007). The isotope data were compared with other gas phase and aerosol parameters related to wood burning, mainly $\mathrm{CO} / \mathrm{NO}_{\mathrm{x}}$ ratios and aerosol light absorption measured by an aethalometer. For evaluating different sources to $\mathrm{CO}$, we used an isotope mass balance model, a model based on $\mathrm{CO} / \mathrm{NO}_{\mathrm{x}}$ ratios and a combination of both. The main aim of the study presented here was to assess the use of highfrequency isotope data of $\mathrm{CO}$ for distinguishing between wood combustion and fossil fuel sources.

\section{Materials and methods}

\subsection{Sampling}

Samples were collected during two campaigns in Southern Switzerland, investigating a village site (Roveredo, $46^{\circ} 14^{\prime} 18^{\prime \prime} \mathrm{N}, 9^{\circ} 07^{\prime} 45^{\prime \prime} \mathrm{E}, 298 \mathrm{~m}$ a.s.l.) and a site close to a motorway (Moleno, $46^{\circ} 16^{\prime} 46^{\prime \prime} \mathrm{N}, 8^{\circ} 59^{\prime} 49^{\prime \prime} \mathrm{E}, 254 \mathrm{~m}$ a.s.1.), complemented by one measurement period in a rural area in Northern Switzerland (Paul Scherrer Institute, PSI, $47^{\circ} 32^{\prime} 15^{\prime \prime} \mathrm{N}, 8^{\circ} 13^{\prime} 37^{\prime \prime} \mathrm{E}, 335 \mathrm{~m}$ a.s.l.) and a wood stove experiment at the test facility of the EMPA (Dübendorf). Roveredo is located in an Alpine valley (Mesolcina) with often strong and stable temperature inversion prevailing during winter, influenced by local heating and traffic from a transit route (San Bernardino route). A large percentage of the people of Roveredo burn wood for domestic heating purposes (75\% of the heating installations are fuelled by wood). An intensive measurement campaign took place here in January 2005, with sampling for isotopes of carbon monoxide from 11-13 January with a time-resolution of approximately $30 \mathrm{~min}$. The Moleno site was located on a parking lot directly at the Gotthard motorway (average traffic density 19700 vehicles per day), while the next village is in a distance of $800 \mathrm{~m}$. Due to the direction and dimensions of the valley, the sun is more often reaching the valley bottom compared to the Roveredo site and therefore comparably more convection is taking place during daytime in winter. Sampling took place during February 2005, specifically on 8 to 9 February for the isotopes. The measurement period near PSI was conducted from 3 to 16 February. The PSI is located in a rural area with forests and agricultural fields nearby, influenced by minor emissions from traffic. During all campaigns, meteorological parameters as well as $\mathrm{CO}, \mathrm{NO}_{\mathrm{x}}$ and $\mathrm{PM}_{10}$ were continuously monitored. 
The wood stove experiment at the test facility of EMPA was conducted during April 2005 (Weimer et al., 2008). For the isotope sampling, a log wood stove was fired with beech $\log$ during 3 consecutive fires of approximately 30 min each. The wood stove was similar to those often used in households for domestic heating purposes, while beech is the main wood type (around $70 \%$ ) burnt in Southern Switzerland. Sampling lines were connected from the exhaust tube of the stove to three dilution stages passing the emissions to a suite of instruments assessing gas phase $\left(\mathrm{CO}, \mathrm{NO}_{\mathrm{x}}\right.$, etc. $)$ and particle properties. Sampling for the isotopes took place after an overall dilution by a factor of 1200 by adding compressed air, which had the main purpose to cool and dilute the effluent gas close to "real-world" conditions and allow condensation of semivolatile particles in reasonable amounts, which is important for the aerosol measurements.

\subsection{Analysis}

Air sampling for the isotope analysis of $\mathrm{CO}$ during all campaigns was done with inhouse-built automated samplers (ASA's) that enable the time-programmed sampling of 33 samples of about $300 \mathrm{ml}$ air in glass flasks (Theis et al., 2004). The air was drawn through magnesium perchlorate traps for drying at a rate of about $11 / \mathrm{min}$, while the actual filling time was set to $3 \mathrm{~min}$. The ASA's have been successfully applied for isotope analysis of $\mathrm{CO}_{2}, \mathrm{CH}_{4}$ and $\mathrm{CO}$ (Theis et al., 2004). After transporting the ASA's to the lab, they were attached to a modified Precon- and Gasbench-preparation unit (Thermo Finnigan, Bremen, Germany) for automated analysis. Isotopic carbon and oxygen isotope analysis was done in continuous-flow mode according to (Mak and Yang, 1998). In short, air samples passed through a liquid nitrogen trap and ascarite trap for complete removal of $\mathrm{CO}_{2}$. Then $\mathrm{CO}$ was converted to $\mathrm{CO}_{2}$ in a glass tube filled with Schütze reagent. The evolving $\mathrm{CO}_{2}$ was first trapped in a loop submersed in liquid nitrogen and then passed through a Poraplotcolumn before entering the mass-spectrometer (Delta-plus XL, Thermo Finnigan, Bremen, Germany). Isotope ratios are given as $\delta$-values and expressed as relative deviations from the international standard, which is VPDB for carbon and VSMOW for oxygen (Saurer et al., 1998). As one oxygen-atom is added to $\mathrm{CO}$ in the Schütze reactor, a careful calibration and correction is necessary regarding the $\delta^{18} \mathrm{O}$ values (Mak and Yang, 1998). For this purpose, a standard $\mathrm{CO}$ gas with known isotopic composition was analysed in the same way as the samples, which then allowed calculating the isotopic composition of the oxygen of the Schütze reagent by a mass balance calculation. The standard $\mathrm{CO}$ was calibrated vs. VSMOW by analysis of water with a hightemperature pyrolysis-unit and the analysis of intercomparison water samples provided by the International Atomic Energy Agency (Saurer et al., 1998). When filling a complete ASA $(n=33)$ with a reference gas of $0.5 \mathrm{ppm} \mathrm{CO}$ in synthetic air $\left(\mathrm{N}_{2} / \mathrm{O}_{2}\right)$, a standard deviation of $0.3 \%$ o resulted for $\delta^{18} \mathrm{O}$, and $0.2 \%$ for $\delta^{13} \mathrm{C}$. Overall, $\mathrm{CO}$ isotopic values from 535 air samples are presented in this paper.

During the Roveredo campaign, aerosol light absorption was measured with a seven-wavelength aethalometer (Magee Scientific, $\lambda=370,470,520,590,660,880$ and $950 \mathrm{~nm})$ that was connected to a whole-air inlet without size-cut (Sandradewi et al., 2008b). This instrument collected the aerosols on quartz fibre filters at a flow rate of $2.5 \pm 0.1 \mathrm{lpm}$ and recorded the data every $2 \mathrm{~min}$. The absorption coefficient $b_{\text {abs }}$ indicating the light attenuation through the aerosol layer on the filter was calculated according to Lambert-Beer's law (Sandradewi et al., 2008a). Based on the different wavelength dependence of $b_{\mathrm{abs}}$ for wood burning (wb) and trafficrelated particles, the contribution of these two sources to the absorption coefficients was calculated. The obtained $b_{\text {abs }}$ for pure wood burning at $470 \mathrm{~nm}$ and pure traffic at $950 \mathrm{~nm}$ were used in a linear model to estimate the fractional contribution of particulate matter (PM) from wood burning to the total PM, expressed as $\mathrm{PM}_{\mathrm{wb}} /\left(\mathrm{PM}_{\mathrm{wb}}+\mathrm{PM}_{\text {traffic }}\right)$ (Sandradewi et al., 2008a).

\subsection{Calculations}

\subsubsection{Isotope mass balance}

Assuming a gas sample to be a mixture of compounds 1, 2, $\ldots \mathrm{N}$ with concentrations or mass $\mathrm{m}_{1}, \mathrm{~m}_{2}, \ldots \mathrm{m}_{N}$, with the total mass

$m_{\text {total }}=\sum_{i=1}^{N} m_{i}$,

assuming further that the isotopic composition of the element of interest of each compound is $\delta_{1}, \delta_{2}, \ldots \delta_{N}$, then the isotopic composition of the mixture is due to mass balance given as:

$\delta_{\text {mixture }} \approx \frac{\sum_{i=1}^{N} m_{i} \delta_{i}}{\sum_{i=1}^{N} m_{i}}$

This equation will be applied in the following to describe the isotopic composition of $\mathrm{CO}$ of an air sample as a mixture of different sources. Equation (2) would be mathematically correct when using just the mass of ${ }^{12} \mathrm{C}^{16} \mathrm{O}$ isotopologues, but is also a good approximation when using the total mass of $\mathrm{CO}$.

\subsubsection{The Keeling-plot approach}

A special case of the isotope mass balance is a gas sample taken as the mixture of 2 compounds, namely background air $\left(\delta_{\text {bgd }}, \mathrm{m}_{\mathrm{bgd}}\right)$, and a pollutant $\left(\delta_{\mathrm{p}}, \mathrm{m}_{\mathrm{p}}\right)$. The isotope ratio of the gas mixture is then given by

$\delta_{\text {mixture }} \approx \frac{\mathrm{m}_{\text {bgd }} \delta_{\text {bgd }}+\mathrm{m}_{\mathrm{p}} \delta_{\mathrm{p}}}{\mathrm{m}_{\mathrm{bgd}}+\mathrm{m}_{\mathrm{p}}}$ 
This equation can be rearranged as:

$\delta_{\text {mixture }} \approx$

$\frac{\mathrm{m}_{\text {bgd }} \delta_{\text {bgd }}+\left(\mathrm{m}_{\text {mixture }}-\mathrm{m}_{\text {bgd }}\right) \delta_{\mathrm{p}}}{\mathrm{m}_{\text {mixture }}}=\frac{\mathrm{m}_{\text {bgd }}\left(\delta_{\text {bgd }}-\delta_{\mathrm{p}}\right)}{\mathrm{m}_{\text {mixture }}}+\delta_{\mathrm{p}}$.

Taking the background concentration, the background isotope ratio and the isotopic composition of the pollutant as

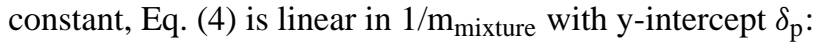

$\delta_{\text {mixture }} \approx \frac{\text { const. }}{m_{\text {mixture }}}+\delta_{p}$

This equation is very useful because it enables deriving the isotope value of the "pure" pollutant $\left(\delta_{\mathrm{p}}\right)$ from a scatter plot of the measured isotope ratios of air samples as a function of the inverse of the measured concentrations, without any further knowledge required about mixing ratios or isotope ratio of the background (Pataki et al., 2003). With some limitations, Eq. (5) is also applicable for more complex mixtures, assuming e.g. the pollutant to be itself a mixture of two pollutants. The y-intercept can then be interpreted as the isotope ratio of the pollutant mixture, but the linearity of Eq. (5) does not strictly hold when the pollutant composition is variable.

\subsubsection{Isotope source separation}

Ideally, one would like to solve the isotope mass balance (Eqs. 1, 2) for the different contributions $m_{i}$. For our case, we assume three sources - traffic (t), wood burning (wb) and background (bgd) -, contributing with $\mathrm{m}_{\mathrm{t}}, \mathrm{m}_{\mathrm{wb}}$ and $\mathrm{m}_{\mathrm{bgd}}$ to total $\mathrm{CO}\left(\mathrm{m}_{\mathrm{total}}\right)$, being characterized by the isotope ratios $\delta_{\mathrm{t}}$, $\delta_{\mathrm{wb}}, \delta_{\text {bgd }}$ and $\delta_{\text {total }}$ :

$\delta_{\text {total }} \mathrm{m}_{\text {total-CO }} \approx$

$\delta_{\text {bgd }} \mathrm{m}_{\mathrm{bgd}-\mathrm{CO}}+\delta_{t} \mathrm{~m}_{\mathrm{t}-\mathrm{CO}}+\delta_{\mathrm{wb}} \mathrm{m}_{\mathrm{wb}-\mathrm{CO}}$

$\mathrm{m}_{\text {total- } \mathrm{CO}} \approx \mathrm{m}_{\mathrm{bgd}-\mathrm{CO}}+\mathrm{m}_{\mathrm{t}-\mathrm{CO}}+\mathrm{m}_{\mathrm{wb}-\mathrm{CO}}$

While the $\mathrm{m}_{\text {total }}$ and $\delta_{\text {total }}$ can be measured, the main difficulty here is that we have to know the pure source isotope values $\delta_{\mathrm{bgd}}, \delta_{\mathrm{t}}$ and $\delta_{\mathrm{wb}}$, which also should be constant over time. Under certain conditions, we further assume a known and constant contribution of the $\mathrm{CO}$ background air, $\mathrm{m}_{\mathrm{bgd}-\mathrm{CO}}=\mathrm{const}$. The validity of these four assumptions will be discussed later in detail. Accordingly, the isotope mass balance equations reduce to a system of two equations with two unknowns $\left(\mathrm{m}_{\mathrm{t}-\mathrm{CO}}, \mathrm{m}_{\mathrm{wb}-\mathrm{CO}}\right)$ and can therefore be solved, for instance, for the contribution of wood burning to the total CO:

$\mathrm{m}_{\mathrm{wb}-\mathrm{CO}} \approx$

$\frac{\left(\delta_{\text {total }}-\delta_{\mathrm{t}}\right) m_{\text {total }-\mathrm{CO}}+\left(\delta_{\mathrm{t}}-\delta_{\mathrm{bgd}}\right) \mathrm{m}_{\mathrm{bgd}-\mathrm{CO}}}{\left(\delta_{\mathrm{wb}}-\delta_{\mathrm{t}}\right)}$.

The fractional contribution of wood-burning is then given by $\mathrm{m}_{\mathrm{wb}-\mathrm{CO}} / \mathrm{m}_{\text {total}-\mathrm{CO}}$.

\subsubsection{CO-NO ${ }_{\mathrm{x}}$ linear model}

In this paragraph, we consider the gas phase concentrations (not isotope ratios) of $\mathrm{NO}_{\mathrm{x}}$ and $\mathrm{CO}$, expressed for instance as partial pressures. Let's take a gas sample with concentrations $\mathrm{c}\left(\mathrm{NO}_{\mathrm{x}}\right)$ and $\mathrm{c}(\mathrm{CO})$, which is a mixture of background air $\left(\mathrm{CO}^{\text {bgd }}, \mathrm{NO}_{\mathrm{x}}^{\text {bgd }}\right)$, traffic emissions $\left(\mathrm{CO}^{\mathrm{t}}, \mathrm{NO}_{\mathrm{x}}^{\mathrm{t}}\right)$ and wood burning $\left(\mathrm{CO}^{\mathrm{wb}}, \mathrm{NO}_{\mathrm{x}}^{\mathrm{wb}}\right)$. This may be expressed as

$\mathrm{c}\left(\mathrm{NO}_{\mathrm{x}}\right)=\mathrm{c}\left(\mathrm{NO}_{\mathrm{x}}^{\mathrm{bgd}}\right)+\mathrm{c}\left(\mathrm{NO}_{\mathrm{x}}^{\mathrm{t}}\right)+\mathrm{c}\left(\mathrm{NO}_{\mathrm{x}}^{\mathrm{wb}}\right)$

$\mathrm{c}(\mathrm{CO})=\mathrm{c}\left(\mathrm{CO}^{\mathrm{bgd}}\right)+\mathrm{c}\left(\mathrm{CO}^{\mathrm{t}}\right)+\mathrm{c}\left(\mathrm{CO}^{\mathrm{wb}}\right)$

Without any additional assumptions, it is not possible to extract these 6 different contributions to the measured $\mathrm{c}(\mathrm{CO})$ and $\mathrm{c}\left(\mathrm{NO}_{\mathrm{x}}\right)$. However, when assuming 1) that the background is known and constant, $\mathrm{c}\left(\mathrm{CO}^{\text {bgd }}\right)=\mathrm{c}_{\text {const }}\left(\mathrm{CO}^{\text {bgd }}\right)$ and $\mathrm{c}\left(\mathrm{NO}_{\mathrm{x}}^{\text {bgd }}\right)=\mathrm{c}_{\text {const }}\left(\mathrm{NO}_{\mathrm{x}}^{\mathrm{bgd}}\right)$, and 2$)$ that the ratios $\mathrm{c}\left(\mathrm{CO}^{\mathrm{t}}\right) / \mathrm{c}\left(\mathrm{NO}_{\mathrm{x}}^{\mathrm{t}}\right)=r_{\mathrm{t}}$ and $\mathrm{c}\left(\mathrm{CO}^{\mathrm{wb}}\right) / \mathrm{c}\left(\mathrm{NO}_{\mathrm{x}}^{\mathrm{wb}}\right)=r_{\mathrm{wb}}$ are known and constant, then there is a solution. The first assumption (constant background) may be valid depending on the actual weather conditions for a limited time period. The second assumption is based on distinct $\mathrm{CO} / \mathrm{NO}_{\mathrm{x}}$ emission ratios for traffic emissions and wood burning (where the ratio is much larger for wood burning). By using these definitions and replacing $\mathrm{c}\left(\mathrm{NO}_{\mathrm{x}}^{\mathrm{t}}\right)$ and $\mathrm{c}\left(\mathrm{NO}_{\mathrm{x}}^{\mathrm{wb}}\right)$ in Eq. (10) with the help of the newly defined ratios, Eqs. 9 and 10 can be rewritten as:

$\mathrm{c}\left(\mathrm{NO}_{\mathrm{x}}\right)=\mathrm{c}_{\mathrm{const}}\left(\mathrm{NO}_{\mathrm{x}}^{\mathrm{bgd}}\right)+\frac{\mathrm{c}\left(\mathrm{CO}^{\mathrm{t}}\right)}{\mathrm{r}_{\mathrm{t}}}+\frac{\mathrm{c}\left(\mathrm{CO}^{\mathrm{wb}}\right)}{\mathrm{r}_{\mathrm{wb}}}$

$\mathrm{c}(\mathrm{CO})=\mathrm{c}_{\text {const }}\left(\mathrm{CO}^{\mathrm{bgd}}\right)+\mathrm{c}\left(\mathrm{CO}^{\mathrm{t}}\right)+\mathrm{c}\left(\mathrm{CO}^{\mathrm{wb}}\right)$,

which are two equations for the two unknowns $\mathrm{c}\left(\mathrm{CO}^{\mathrm{t}}\right)$ and $\mathrm{c}\left(\mathrm{CO}^{\mathrm{wb}}\right)$. Solving for $\mathrm{c}\left(\mathrm{CO}^{\mathrm{wb}}\right)$, the concentration of $\mathrm{CO}$ originating from wood burning emissions, leads to:

$$
\begin{aligned}
& \mathrm{c}\left(\mathrm{CO}^{\mathrm{wb}}\right)=\frac{r_{\mathrm{wb}}}{r_{\mathrm{t}}-r_{\mathrm{wb}}}\left(\mathrm{c}_{\mathrm{const}}\left(\mathrm{CO}^{\mathrm{bgd}}\right)-\mathrm{c}(\mathrm{CO})+\right. \\
& \left.r_{\mathrm{t}}\left[\mathrm{c}\left(\mathrm{NO}_{\mathrm{x}}\right)-\mathrm{c}_{\text {const }}\left(\mathrm{NO}_{\mathrm{x}}^{\mathrm{bgd}}\right)\right]\right)
\end{aligned}
$$

and therefore based on (12) for traffic:

$$
\begin{aligned}
& \mathrm{c}\left(\mathrm{CO}^{\mathrm{t}}\right)=\frac{r_{\mathrm{t}}}{r_{\mathrm{t}}-r_{\mathrm{wb}}}\left(\mathrm{c}(\mathrm{CO})-\mathrm{c}_{\mathrm{const}}\left(\mathrm{CO}^{\mathrm{bgd}}\right)+\right. \\
& \left.r_{\mathrm{wb}}\left[\mathrm{c}\left(\mathrm{NO}_{\mathrm{X}}\right)-\mathrm{c}_{\mathrm{const}}\left(\mathrm{NO}_{\mathrm{X}}^{\mathrm{bgd}}\right)\right]\right)
\end{aligned}
$$

Dividing these concentrations by $\mathrm{c}(\mathrm{CO})$ results in the fractional contributions of wood-burning and traffic to $\mathrm{CO}$ (or the contribution in $\%$ by multiplying with 100 ), which may be directly compared to the results from the isotope source separation $\mathrm{m}_{\mathrm{wb}-\mathrm{CO}} / \mathrm{m}_{\text {total-CO}}$ and $\mathrm{m}_{\mathrm{t}-\mathrm{CO}} / \mathrm{m}_{\text {total-CO}}$. A graphical representation of the model will be shown later. 


\subsubsection{Combined $\mathrm{CO} / \mathrm{NO}_{\mathrm{x}}$ isotope model}

Based on the isotope mass-balance (Eq. 2), we describe the isotopic composition of $\mathrm{CO}$ of an air sample $\left(\delta_{\mathrm{s}}\right)$ as a mixture of $\mathrm{CO}$ from background air $\left(\delta_{\mathrm{bgd}}, \mathrm{m}_{\mathrm{bgd}-\mathrm{CO}}\right), \mathrm{CO}$ from traffic $\left(\delta_{\mathrm{t}}, \mathrm{m}_{\mathrm{t}-\mathrm{CO}}\right)$ and $\mathrm{CO}$ from wood burning $\left(\delta_{\mathrm{wb}}, \mathrm{m}_{\mathrm{wb}-\mathrm{CO}}\right)$ :

$\delta_{\mathrm{s}}=\frac{\delta_{\mathrm{bgd}} \mathrm{m}_{\mathrm{bgd}-\mathrm{CO}}+\delta_{\mathrm{t}} \mathrm{m}_{\mathrm{t}-\mathrm{CO}}+\delta_{\mathrm{wb}} \mathrm{m}_{\mathrm{wb}-\mathrm{CO}}}{\mathrm{m}_{\mathrm{bgd}-\mathrm{CO}}+\mathrm{m}_{\mathrm{t}-\mathrm{CO}}+\mathrm{m}_{\mathrm{wb}-\mathrm{CO}}}$

Using the above $\mathrm{CO} / \mathrm{NO}_{\mathrm{x}}$ model and the assumptions therein, the coefficients $\mathrm{m}_{\mathrm{t}-\mathrm{CO}}$ and $\mathrm{m}_{\mathrm{wb}-\mathrm{CO}}$ can be calculated for every air sample from the measurement of $\mathrm{c}(\mathrm{CO})$ and $\mathrm{c}\left(\mathrm{NO}_{\mathrm{x}}\right)$ using the expressions derived in Eqs. (13 and 14) (the background concentrations are still taken as constant). When the isotope ratios of the three sources are known, Eq. (15) can thus be solved and this calculated value compared with the measured isotope ratio of $\mathrm{CO}$ of a gas sample. (A similar equation could also be written for the isotope mass balance of $\mathrm{NO}_{\mathrm{x}}$, but this is not further discussed here due to the lack of isotope data of $\mathrm{NO}_{\mathrm{x}}$ ). The purpose of the combined $\mathrm{CO} / \mathrm{NO}_{\mathrm{x}}$ isotope model is the verification of the isotope mass balance (Eqs. 6-8).

\section{Results}

\subsection{Wood stove experiment}

Figure 1 shows $\delta^{18} \mathrm{O}$ of $\mathrm{CO}$ plotted versus the inverse of the $\mathrm{CO}$ concentration $1 / \mathrm{c}(\mathrm{CO})$ from three fires of the combustion of beech logs in a controlled setting. While one fire lasted approximately 30 minutes, samples correspond to three minute filling time of the sample containers and were taken three times during each fire. $\mathrm{CO}$ concentrations were not constant during the fires, due to different combustion temperatures (Weimer et al., 2008). Additionally, the mixing of the combustion gas with the dilution gas (compressed air) has to be considered. The mixing line in Fig. 1 therefore should mainly be interpreted for the y-intercept, which corresponds to the pure wood-burning $\delta^{18} \mathrm{O}$ signal according to the Keeling-plot equations (Eqs. 3-5), while the other end-member is determined by isotopic signal of the dilution air, which must have a relatively low $\delta^{18} \mathrm{O}$ value. The $\mathrm{y}$ intercept indicating the oxygen isotope signal from the combustion source was similar for all three batches, with an average of $16.3 \% \circ \pm 0.6 \%$. The corresponding $\delta^{13} \mathrm{C}$-signal was $-24.7 \%$ o $\pm 1.0 \%$. The obtained value for $\delta^{18} \mathrm{O}$ of $\mathrm{CO}$ from wood combustion is clearly lower than the values commonly observed for traffic emissions, which should be close to the value of atmospheric oxygen $\left(\mathrm{O}_{2}\right)$ of $23.88 \%$ o. Accordingly, a significant difference results between $\delta^{18} \mathrm{O}$ of $\mathrm{CO}$ from wood heating and from traffic emissions (Fig. 1).

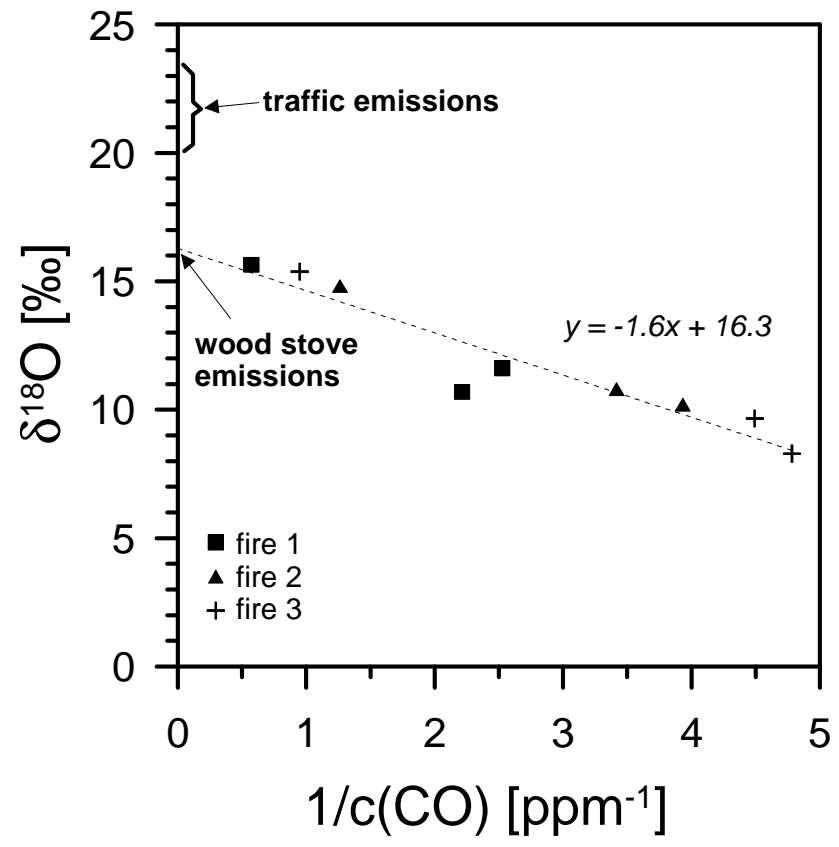

Fig. 1. Oxygen isotope ratios of $\mathrm{CO}$ as a function of the inverse of the CO-concentration $1 / \mathrm{c}(\mathrm{CO})$ for the EMPA wood stove experiment, in comparison with the estimated range of values for traffic emissions.

\subsection{Roveredo and Moleno: data overview}

Isotope ratios and concentrations of $\mathrm{CO}$ are shown for a 48$\mathrm{h}$ period in winter in Roveredo (Fig. 2), the village site affected mainly by domestic heating and to a minor degree by traffic emissions. The $\delta^{18} \mathrm{O}$ data show a very pronounced diurnal pattern with relatively low values in the night, a steep increase in the morning hours and high values during the day. The amplitude of this consistent signal over 2 days is almost $8 \%$. A diurnal pattern is also visible in $\mathrm{c}(\mathrm{CO})$, but with much higher noise (individual peaks) relative to the diurnal amplitude. In contrast, the $\delta^{13} \mathrm{C}$ data do not show any diurnal variation. A relatively high pollution level is evident from the range of $\mathrm{c}(\mathrm{CO})$ from 300 to $1200 \mathrm{ppb}$ and $\mathrm{c}\left(\mathrm{NO}_{\mathrm{x}}\right)$ from 10 to $140 \mathrm{ppb}$, which may be explained by the stable weather conditions with strong inversions and low wind speed during this period (Sandradewi et al., 2008b). The influence of $\mathrm{NO}_{\mathrm{x}}$ products on the $\mathrm{NO}_{\mathrm{x}}$ signal of the conventional instrument used (Steinbacher et al., 2007) can be assumed to be negligible in winter at these concentrations. Only during night, the downslope winds were carrying relatively clean air and diluted the air at the bottom of the valley, where also the low emissions during the night contributed little as evident from low $\mathrm{c}\left(\mathrm{NO}_{\mathrm{x}}\right)$, in particular from 03:00 to 06:00 a.m. (Prévôt et al., 2000b). $\mathrm{CO} / \mathrm{NO}_{\mathrm{x}}$ concentration ratios were strongly enriched during the night, when traffic was minimal. It is known that due to a lower combustion temperature, much more $\mathrm{CO}$ and less $\mathrm{NO}_{\mathrm{x}}$ is emitted 

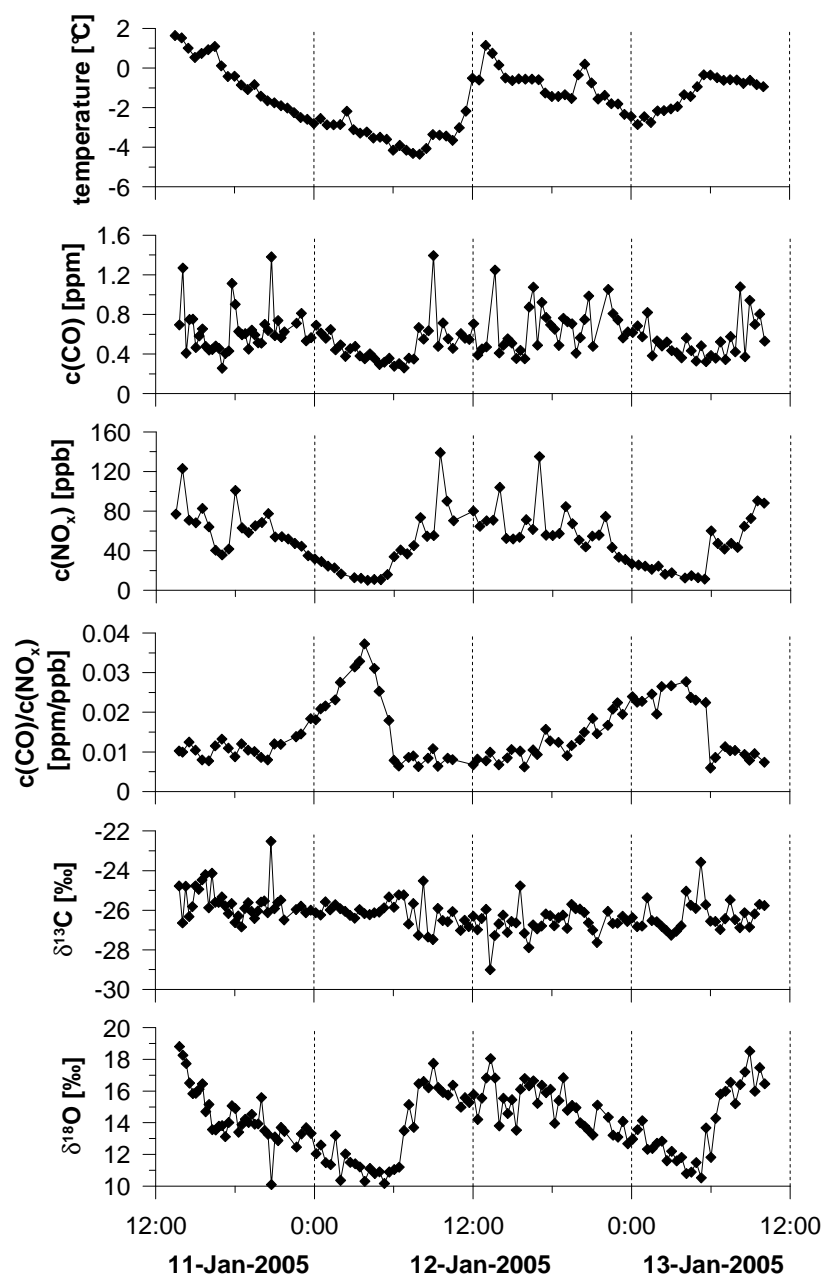

Fig. 2. Temporal evolution of temperature, $\mathrm{c}(\mathrm{CO}), \mathrm{c}\left(\mathrm{NO}_{\mathrm{x}}\right)$, $\mathrm{c}(\mathrm{CO}) / \mathrm{c}\left(\mathrm{NO}_{\mathrm{x}}\right)$, carbon and oxygen isotope ratios of $\mathrm{CO}$ over $48 \mathrm{~h}$ in winter in the village Roveredo, Switzerland.

by wood combustion compared to traffic (Johansson et al., 2004; Kirchstetter et al., 1999). Therefore, the ratio $\mathrm{CO} / \mathrm{NO}_{\mathrm{x}}$ can be used as an indicator for the relative emission strength of wood burning and traffic. Qualitatively, it seems obvious that the low $\delta^{18} \mathrm{O}$ values and high $\mathrm{CO} / \mathrm{NO}_{\mathrm{x}}$ in Roveredo at night reflect the influence of wood burning. This will be discussed in more detail in the following.

For similar weather conditions as above (cold, low wind), the pollution situation and isotope values were assessed for a 24-h period in Moleno, a site close to a motorway, more than $600 \mathrm{~m}$ distant to the next small village (Fig. 3). Here, we observed the highest pollution during the night and early morning (not during the day as in Roveredo), which is probably caused by convection occurring during the day due to insolation and subsequent dilution of the polluted air, as reflected also in higher wind speeds around midday (data not shown). The concentrations of $\mathrm{CO}$ and $\mathrm{NO}_{\mathrm{x}}$ were higher than in Roveredo, with $\mathrm{c}\left(\mathrm{NO}_{\mathrm{x}}\right)$ reaching $500 \mathrm{ppb}$ in the morning
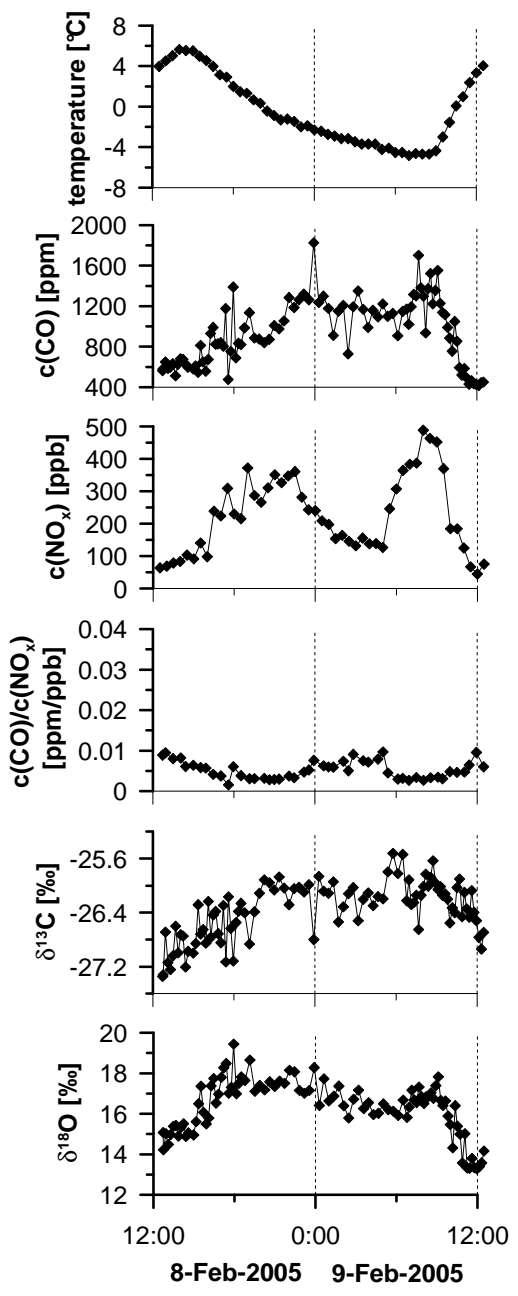

Fig. 3. Temporal evolution of temperature, $\mathrm{c}(\mathrm{CO}), \mathrm{c}\left(\mathrm{NO}_{\mathrm{x}}\right)$, $\mathrm{c}(\mathrm{CO}) / \mathrm{c}\left(\mathrm{NO}_{\mathrm{x}}\right)$, carbon and oxygen isotope ratios of $\mathrm{CO}$ over $24 \mathrm{~h}$ in winter near a motorway (Moleno, Switzerland).

rush hour. Two maxima per day were observed for $\mathrm{c}\left(\mathrm{NO}_{\mathrm{x}}\right)$, clearly reflecting the traffic density and mixing during the day. The oxygen isotope data of $\mathrm{CO}$ also showed a diurnal signal (Fig. 3), following the pollution trends with higher values during the day than in the night, but with a smaller amplitude (about 4\%o) than in Roveredo. The time course of the $\mathrm{CO} / \mathrm{NO}_{\mathrm{x}}$ concentration ratio indicated very low values compared to Roveredo throughout all the measured period. The $\delta^{13} \mathrm{C}$ values of $\mathrm{CO}$ tended to be higher during the day than during the night, however, by less than $1 \%$.

\subsection{Comparison with indicators for wood combustion versus traffic}

In Fig. 4, we show the data of $\delta^{18} \mathrm{O}$ of $\mathrm{CO}$ for Roveredo together with parameters related to aerosol light absorption $\left(b_{a b s}\right.$ at $470 \mathrm{~nm}$ and $950 \mathrm{~nm}$ ), and thereof calculated contribution of wood burning to particulate matter 


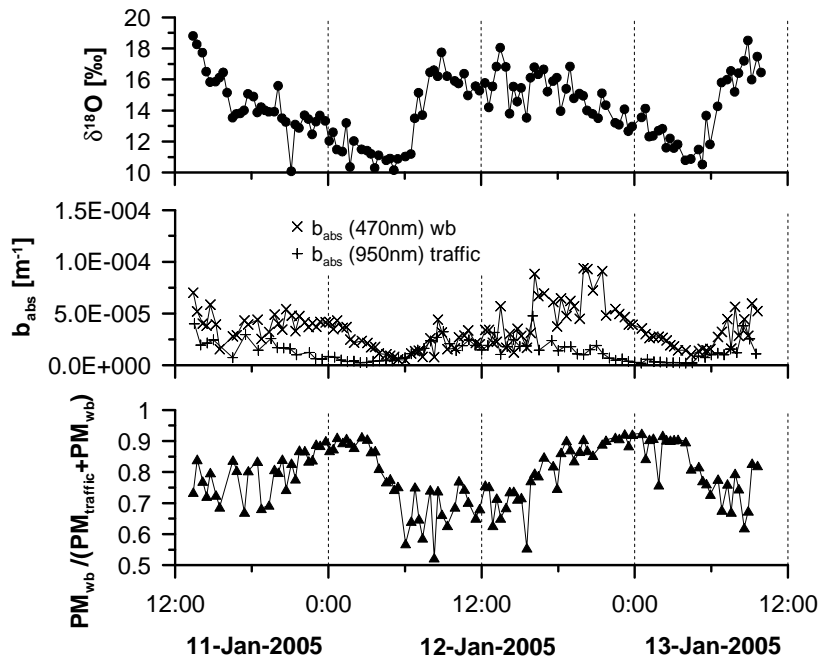

Fig. 4. Comparison of $\delta^{18} \mathrm{O}$ of $\mathrm{CO}$ with aethalometer results (aerosol light absorption coefficient $b_{\mathrm{abs}}$ and calculated proportion of PM from wood burning) for the measurement campaign in Roveredo.

$\mathrm{PM}_{\mathrm{wb}} /\left(\mathrm{PM}_{\mathrm{wb}}+\mathrm{PM}_{\text {traffic }}\right) . \delta^{18} \mathrm{O}$ of $\mathrm{CO}$ shows an opposite diurnal pattern compared to the light absorption parameters, with either a maximum or a minimum in the early morning hours and a subsequent steep decrease or increase after the onset of traffic. Aerosol light absorption studies on wood smoke using an aethalometer showed that organic compounds in aerosols from wood combustion result in a strong UV absorption measured at low wavelengths, e.g at $470 \mathrm{~nm}$, whereas absorption of traffic-originating particles dominates at higher wavelengths, e.g. at $950 \mathrm{~nm}$ (Jeong et al., 2004). Accordingly, the diurnal course of the absorption coefficient $b_{\mathrm{abs}}(470 \mathrm{~nm})_{\mathrm{wb}}$ indicates a dominant influence of wood burning during night on the total particle load. Based on the source separation model and calculation of $\mathrm{PM}_{\mathrm{wb}} /\left(\mathrm{PM}_{\mathrm{wb}}+\mathrm{PM}_{\text {traffic }}\right)$ (Sandradewi et al., 2008a), a contribution of wood burning up to $90 \%$ during night was obtained. During the day, the relative $\mathrm{PM}_{\mathrm{wb}}$ amount was 50$70 \%$, with significant short-term variability. All parameters shown in Fig. 4 therefore indicate the maximum contribution of wood combustion to the pollution load at a similar time of the day. The linear correlation coefficient between the isotope ratio and $\mathrm{PM}_{\mathrm{wb}} /\left(\mathrm{PM}_{\mathrm{wb}}+\mathrm{PM}_{\text {traffic }}\right)$ is $r=-0.58$.

\subsection{Keeling plot analysis}

The relationship between CO-concentrations $\mathrm{c}(\mathrm{CO})$ and $\delta^{18} \mathrm{O}$ was analysed by a Keeling-plot-approach for both sites (Fig. 5). However, Keeling-plots need some care in the interpretation in a situation where the air is originating from more than two sources (see also 2.3.2). Varying contributions of background, traffic and wood combustion emissions violate the assumption of a two end-member model. Indeed, the explained variance for the correlation of $\delta^{18} \mathrm{O}_{\mathrm{CO}}$ vs. $1 / \mathrm{c}(\mathrm{CO})$
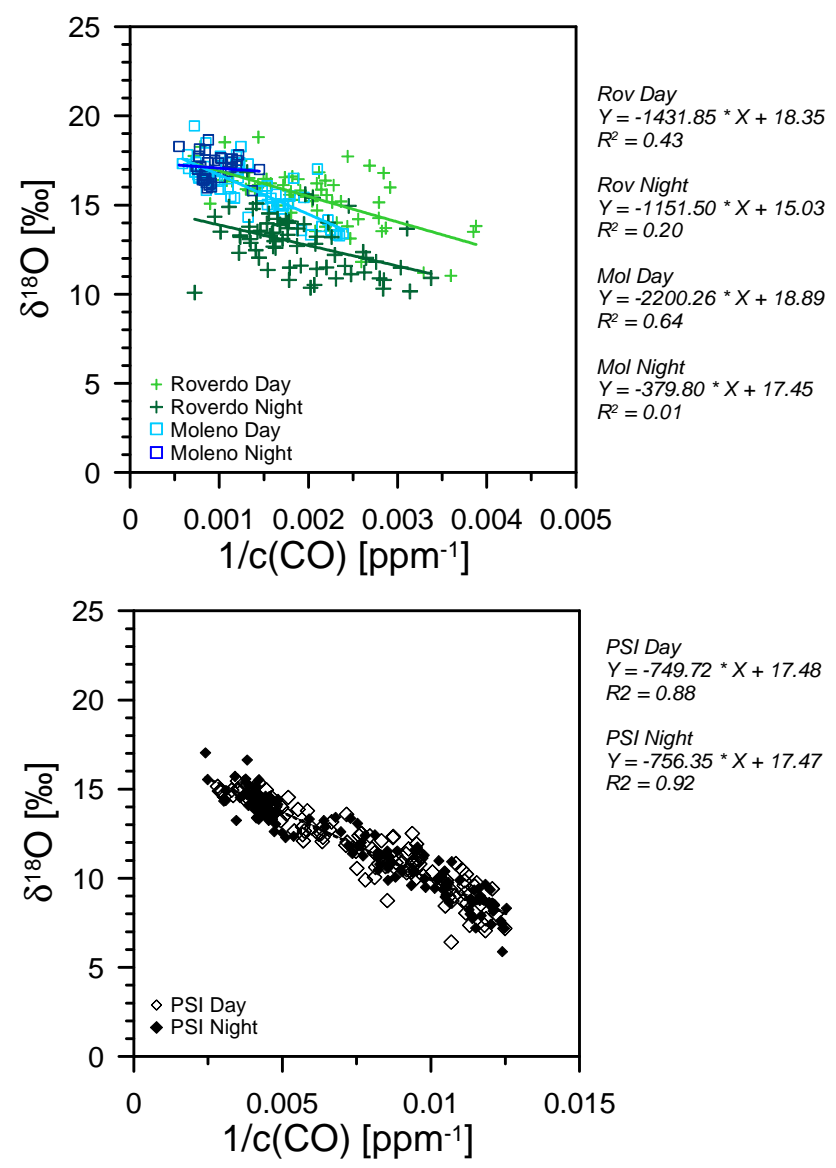

Fig. 5. Keeling plots for Roveredo and Moleno (upper plot) and the rural site PSI (lower plot), separated into day and night values.

is rather low for Roveredo $\left(r^{2}=0.43\right.$ during the day and $r^{2}=0.20$ during the night), with y-intercepts of $18.35 \%$ and $15.03 \%$ o during the day and night, respectively. In contrast, the same relationship is more linear for Moleno and accordingly yields a much higher correlation coefficient during the day $\left(r^{2}=0.64\right)$, showing that the two-member mixing model may be more viable, with a y-intercept of $18.9 \%$, while the correlation breaks down in the night $\left(r^{2}=0.01\right)$. The lower values for the isotopic signal of the pollution in Roveredo at night indicates the influence of wood combustion, which has a lower ${ }^{18} \mathrm{O}$ content than traffic, resulting in differences of up to $8 \%$ o between the values for Roveredo and Moleno. The values do, however, not match the expected values for "pure" emissions $(23.88 \%$ o for traffic and $16.3 \%$ o for wood combustion), but are lower. This discrepancy could have two reasons: either the presumed source values are not applicable or the assumptions for the application of the Keeling-plot approach are not well enough fulfilled. 
Table 1. CO attributed to different sources as calculated with the isotope mass balance (Eqs. 6-8, parameters according to the base case scenario). Average values for the three investigated sites are shown, where "Day" corresponds to 09:00 a.m.-03:00 p.m. and "Night" to 09:00 p.m.-03:00 a.m.

\begin{tabular}{lcccc}
\hline Site & Day/night & CO from wood burning [\%] & CO from traffic [\%] & CO from background [\%] \\
\hline Roveredo & Day & 35 & 37 & 28 \\
Roveredo & Night & 70 & 2 & 28 \\
Moleno & Day & 42 & 29 & 29 \\
Moleno & Night & 49 & 35 & 16 \\
PSI & Day & 27 & 36 & 37 \\
PSI & Night & 29 & 38 & 33 \\
\hline
\end{tabular}
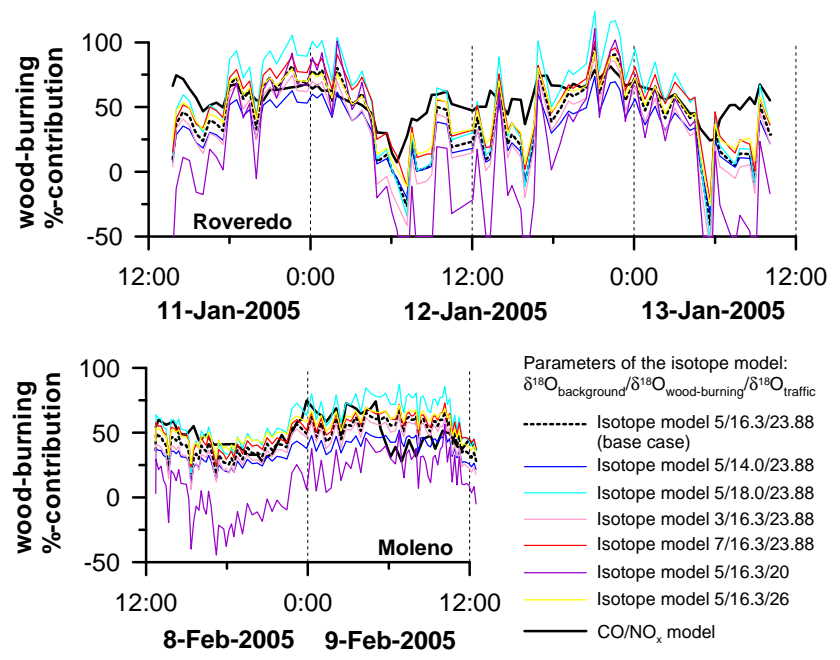

Fig. 6. Calculated wood burning contribution to $\mathrm{CO}\left(\mathrm{m}_{\mathrm{wb}}\right)$ according to the isotope source separation model (Eq. 8) for different input parameters. The results according to the $\mathrm{CO} / \mathrm{NO}_{\mathrm{x}}$ split model are also shown.

\subsection{Source separation based on isotopes}

Based on Eqs. (6-8), the relative contribution of wood burning to the total $\mathrm{CO}$ in an air sample can be estimated from the measurement of the concentration and oxygen isotope ratio of $\mathrm{CO}$, assuming knowledge of the pure source isotope values. Since these source values have some uncertainty, a range of values is considered here. As base case, we take $\delta_{\mathrm{t}}=23.88 \%, \delta_{\mathrm{wb}}=16.3 \%$ (as discussed above) and $\delta_{\mathrm{bgd}}=5 \%$. The isotope source value for the background is particularly uncertain, whereby it is known to be relatively depleted in the heavier isotope (Brenninkmeijer et al., 1999). As a sensitivity test, we used the low and high extreme values of $\delta_{t}=20 \% o$ and $26 \%, \delta_{\mathrm{wb}}=14 \% \circ$ and $18 \% o$ and $\delta_{\mathrm{bgd}}=3 \% o$ and $7 \%$. Further, a background value of $\mathrm{c}\left(\mathrm{CO}^{\mathrm{bgd}}\right)=181 \mathrm{ppm}$ was determined from a regression analysis under early morning conditions (see next section). Accordingly, we calculated the wood burning contribution $\mathrm{m}_{\mathrm{wb}-\mathrm{CO}}$ to the measured $\mathrm{CO}$ concentration for the Roveredo and Moleno campaigns with Eq. (8) (Fig. 6, Table 1). For the base case for Roveredo, we observed a clear diurnal pattern with an average value of $\mathrm{m}_{\mathrm{wb}}=70 \%$ during the night (09:00 p.m. to 03:00 a.m.), and much lower values from $0-50 \%$ during the day. A higher variability is observed during the day when traffic is more frequent. In Fig. 6, also calculated values below zero (which are not possible in reality) are shown for a better assessment of the influence of the source isotope values. Those combinations of source isotope values that result in negative $m_{w b}$ can obviously be considered as not plausible. It is apparent from Fig. 6 that the scenarios with relatively low $\delta^{18} \mathrm{O}$ for the traffic emissions $\left(\delta_{\mathrm{bgd}}=5 \%\right.$; $\delta_{\mathrm{wb}}=16.3 \%$; $\delta_{t}=20 \%$ ) and low $\delta^{18} \mathrm{O}$ for the background $\mathrm{CO}\left(\delta_{\mathrm{bgd}}=3 \% \circ ; \delta_{\mathrm{wb}}=16.3 \%\right.$; $\delta_{t}=23.88 \%$ o $)$ result in the most negative values of $\mathrm{m}_{\mathrm{wb}}$ during the day. On the other hand, the scenario with a high value for the wood burning emissions ( $\delta_{\mathrm{bgd}}=3 \%$; $\delta_{\mathrm{wb}}=18 \%$; $\delta_{t}=23.88 \%$ ) results in values above $100 \%$ during the night, which again is physically not possible. For the Moleno site, a diurnal pattern in $\mathrm{m}_{\mathrm{wb}}$ is also visible, but less pronounced compared to the Roveredo site. Excluding the extreme scenarios as above, the estimated values for $\mathrm{m}_{\mathrm{wb}}$ are $42 \%$ during the day and $49 \%$ during the night (Table 1). The traffic contribution to $\mathrm{CO}$ in Moleno is rather low, considering that the site is close to a motorway. Overall for both sites, a quite strong dependence of the estimated wood burning contribution on the source isotope values is observed.

\section{6 $\mathrm{CO} / \mathrm{NO}_{\mathrm{x}}$-model}

In Fig. 7, a scatter plot of $\mathrm{c}(\mathrm{CO})$ versus $\mathrm{c}\left(\mathrm{NO}_{\mathrm{x}}\right)$ is shown for Roveredo for winter conditions. As mentioned above, the $\mathrm{CO} / \mathrm{NO}_{\mathrm{x}}$ concentration ratio of wood burning emissions is much higher than for traffic emissions. The range of values of $\mathrm{c}(\mathrm{CO}) / \mathrm{c}\left(\mathrm{NO}_{\mathrm{x}}\right)$ observed in actual air samples depends on the contribution of these two sources and the admixture of background (relatively) clean air. The lowest ratios are observed when traffic emissions dominate, which is the case in the morning rush hour (06:00-07:00 a.m.), while the highest ratios are observed after midnight (02:00-03:00 a.m.), when traffic is minimal and heating dominates. Accordingly, 


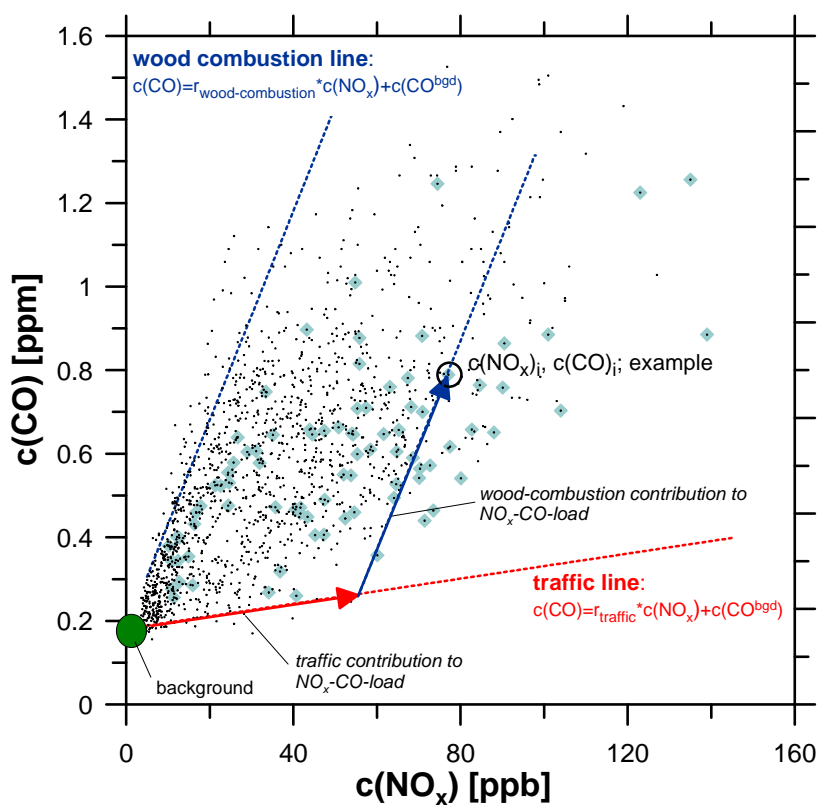

Fig. 7. Scatter plot for $\mathrm{CO}$ and $\mathrm{NO}_{\mathrm{x}}$ data from Roveredo (large symbols: data from 11-13 January 2005, small symbols: data from 1-31 January 2005), shown together with theoretical lines based on pure traffic and pure wood combustion $\mathrm{CO} / \mathrm{NO}_{\mathrm{x}}$ emission ratios. The arrows indicate how an actual sample $\mathrm{c}\left(\mathrm{NO}_{\mathrm{x}}\right)_{\mathrm{i}}, \mathrm{c}(\mathrm{CO})_{\mathrm{i}}$ can be expressed as linear combination of traffic and wood combustion emissions.

we extracted emissions ratios for pure traffic $\left(r_{\mathrm{t}}\right)$ and pure wood burning $\left(r_{\mathrm{wb}}\right)$ by calculating the $\mathrm{CO} / \mathrm{NO}_{\mathrm{x}}$ ratios, using the average of either the lowest $50 \%$ of values (for $r_{\mathrm{t}}$ ) or the highest $50 \%$ values (for $r_{\mathrm{wb}}$ ) of the respective $1 \mathrm{~h}$-time slots. This calculation was done after subtracting a background of $181 \mathrm{ppb}$ for $\mathrm{CO}$ and $5 \mathrm{ppb}$ for $\mathrm{NO}_{\mathrm{x}}$ determined from the $y$-intercept of the regression line for the morning rush hour conditions. We obtained $r_{\mathrm{t}}=0.0015 \mathrm{ppm} / \mathrm{ppb}$ and $r_{\mathrm{wb}}=0.025 \mathrm{ppm} / \mathrm{ppb}$. These pure emission ratios correspond to the slopes indicated in Fig. 7 and represent lower and upper boundaries for the possible $\mathrm{CO}$ and $\mathrm{NO}_{\mathrm{x}}$ compositions. It is now possible extracting the individual contributions of wood burning and traffic with a linear model indicated by the arrows in Fig. 7, which is equivalent to the derivation in Sect. 2.3.4. Uncertainties in this approach are involved with the assumption of a constant background of $\mathrm{c}\left(\mathrm{CO}^{\mathrm{bgd}}\right)=181 \mathrm{ppb}$ and $\left.\mathrm{c}\left(\mathrm{NO}_{\mathrm{x}}^{\mathrm{bgd}}\right)=5 \mathrm{ppb}\right)$ and the way of derivation of values for $r_{\mathrm{t}}$ and $r_{\mathrm{wb}}$. While the first point seems plausible for the short time period where the model actually will be applied ( 2 days), the second point clearly leaves some uncertainty because pure emissions never really occur. Several additional tests were performed to check the plausibility of the $r_{\mathrm{t}}$ and $r_{\mathrm{wb}}$-values. $\mathrm{CO} / \mathrm{NO}_{\mathrm{x}}$ concentration measurements during summer, for instance, were calculated to get an independent estimate of traffic emissions (because heating should be negligible in summer). The value obtained for
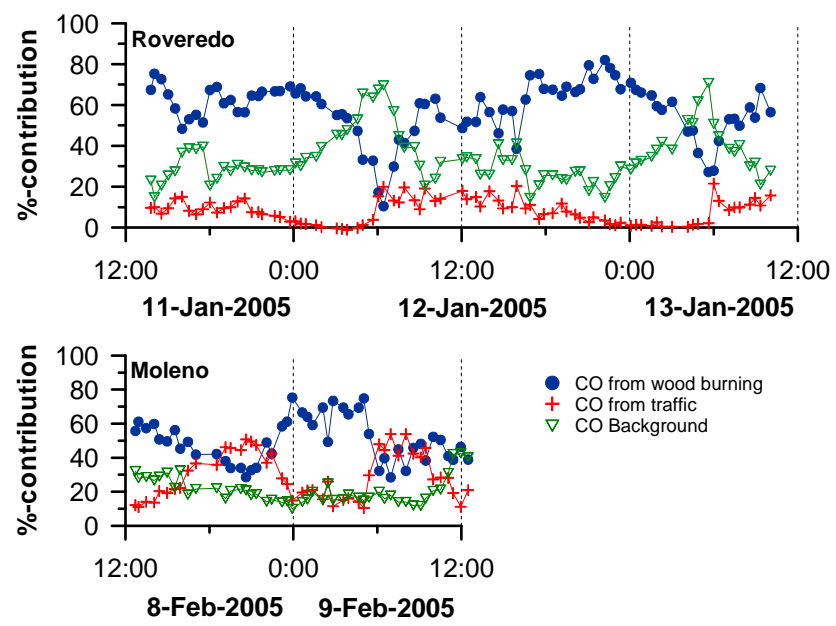

- CO from wood burning

+ CO from traffic
$\nabla$ CO Background

Fig. 8. $\mathrm{CO}$ split into different sources based on the $\mathrm{CO} / \mathrm{NO}_{\mathrm{x}}$ model (Eq. 13).

$r_{\mathrm{t}}$ was higher $(0.003 \mathrm{ppm} / \mathrm{ppb})$, however, the original calculation was kept, because the traffic mix (diesel versus gasoline vehicles) may also be different in summer. Calculations in the following are shown for a range of $r_{b}$ and $r_{\mathrm{wb}}$.

In Fig. 8 (upper graph), the results for the $\mathrm{CO}$ separation into the three sources background, traffic and wood burning are shown for Roveredo, for January 11 to 13 . The separation is based on the best estimates for the parameters as discussed above: $\mathrm{c}\left(\mathrm{CO}^{\mathrm{bgd}}\right)=181 \mathrm{ppb}, \mathrm{c}\left(\mathrm{NO}_{\mathrm{x}}^{\mathrm{bgd}}\right)=5 \mathrm{ppb}$, $r_{\mathrm{t}}=0.0015 \mathrm{ppm} / \mathrm{ppb}, r_{\mathrm{wb}}=0.025 \mathrm{ppm} / \mathrm{ppb}$. The striking features of this Figure are: a) High values for the contribution of $\mathrm{CO}$ from wood burning during most of the day (67\% from 09:00 pm-03:00 a.m., maximum value 82\%), b) a low value of this contribution during a short period in the morning due to admixture of clean background air (during low $\mathrm{CO}$ conditions), c) traffic contributions of not more than $20 \%$ during the day, and even lower during the night. The wood burning contribution as shown in Fig. 8 is also indicated in Fig. 6 for comparison with the calculations based on the isotope mass balance. There is a good agreement between $\mathrm{m}_{\mathrm{wb}}$ calculated with the $\mathrm{CO} / \mathrm{NO}_{\mathrm{x}}$-model and the base case scenario in the isotope-only model, particularly during the night, whereas during the day the $\mathrm{m}_{\mathrm{wb}}$-calculation with the $\mathrm{CO} / \mathrm{NO}_{\mathrm{x}}$ model is higher. Further, the $\mathrm{CO} / \mathrm{NO}_{\mathrm{x}}$ model seems to result in less short-term variability.

The influence of varying emission ratios $r_{\mathrm{t}}$ and $r_{\mathrm{wb}}$ on the $\%$-contribution of CO from wood burning is shown in Table 2 (based on the $\mathrm{CO} / \mathrm{NO}_{\mathrm{x}}$-separation). Both ratios were changed by a factor of 3 . It is obvious from this Table that both increasing $r_{\mathrm{t}}$ at constant $r_{\mathrm{wb}}$ as well as increasing $r_{\mathrm{wb}}$ at constant $r_{\mathrm{t}}$ result in a relatively minor reduction in the calculated $\%$-contribution from wood burning of 2-7\%. Higher deviations were observed for daytime hours, in particular for the morning rush hour, with differences up to $25 \%$ for different emission ratios. 
Table 2. CO originating from wood burning for Roveredo (09:00 p.m.-03:00 a.m., 11-13 January 2005) calculated with the $\mathrm{CO} / \mathrm{NO}_{\mathrm{x}}$ model for varying emissions ratios for traffic $\left(r_{\mathrm{t}}\right)$ and wood burning $\left(r_{\mathrm{wb}}\right)$.

\begin{tabular}{ccc}
\hline$r_{\mathrm{t}}[\mathrm{ppm} / \mathrm{ppb}]$ & $r_{\mathrm{wb}}[\mathrm{ppm} / \mathrm{ppb}]$ & CO from wood burning [\%] \\
\hline 0.001 & 0.02 & 68.8 \\
0.002 & 0.02 & 67.6 \\
0.003 & 0.02 & 66.3 \\
0.001 & 0.04 & 67.2 \\
0.002 & 0.04 & 64.1 \\
0.003 & 0.04 & 61.0 \\
0.001 & 0.06 & 66.4 \\
0.002 & 0.06 & 63.0 \\
0.003 & 0.06 & 59.4 \\
\hline
\end{tabular}

The calculation of the wood burning contribution to $\mathrm{CO}$ for Moleno calculated with the $\mathrm{CO} / \mathrm{NO}_{\mathrm{x}}$-model also yielded high values at night (Fig. 8, lower graph), but these high values were prevalent for a shorter time period compared to Roveredo. The night (09:00 p.m.-03:00 a.m.) average was $57 \%$ calculated with this model and thus somewhat higher than with the isotope mass balance (49\%, see Table 1$)$. The contribution of traffic was higher in Moleno compared to Roveredo for both day and night according to the $\mathrm{CO} / \mathrm{NO}_{\mathrm{x}}{ }^{-}$ model, while this was only the case during the night according to the isotope mass balance.

\subsection{Combined $\mathrm{CO} / \mathrm{NO}_{\mathrm{x}}$-isotope model}

The calculated $\mathrm{CO}$ split into different sources with the $\mathrm{CO} / \mathrm{NO}_{\mathrm{x}}$-model (Fig. 8) was then used as input for the combined $\mathrm{CO} / \mathrm{NO}_{\mathrm{X}}$-isotope model (according to Eq. 15). Taking the base case for the pure source $\delta^{18} \mathrm{O}$ values $(23.88 \%$ ofor traffic, 5\%o for background $\mathrm{CO}$ and $16.3 \%$ of wood burning), the isotopic composition of the air samples was calculated and compared to the measured values (Fig. 9). Generally, there is a good agreement between measured and modelled data for Roveredo $(r=0.67, p<0.001)$, although modelled values are somewhat low during the day (06:00 a.m. to 06:00 p.m.). Nevertheless, the diurnal pattern is well reproduced by the model. The combined $\mathrm{CO} / \mathrm{NO}_{\mathrm{x}}$ isotope model was also applied for Moleno, using the same parameters as in Roveredo. Here, an even better agreement between measured and modelled values was observed ( $r=0.70$, Fig. 9, lower panel).

Besides the uncertainty in the $\mathrm{CO} / \mathrm{NO}_{\mathrm{x}}$ separation due to uncertain emission ratios, the agreement between modelled and measured values depends strongly on the assumed isotope values for the different sources. We assessed the performance of the combined $\mathrm{CO} / \mathrm{NO}_{\mathrm{x}}$-isotope model and its dependence on the used values of the pure isotope sources with a sensitivity analysis for Roveredo (Fig. 10). We varied
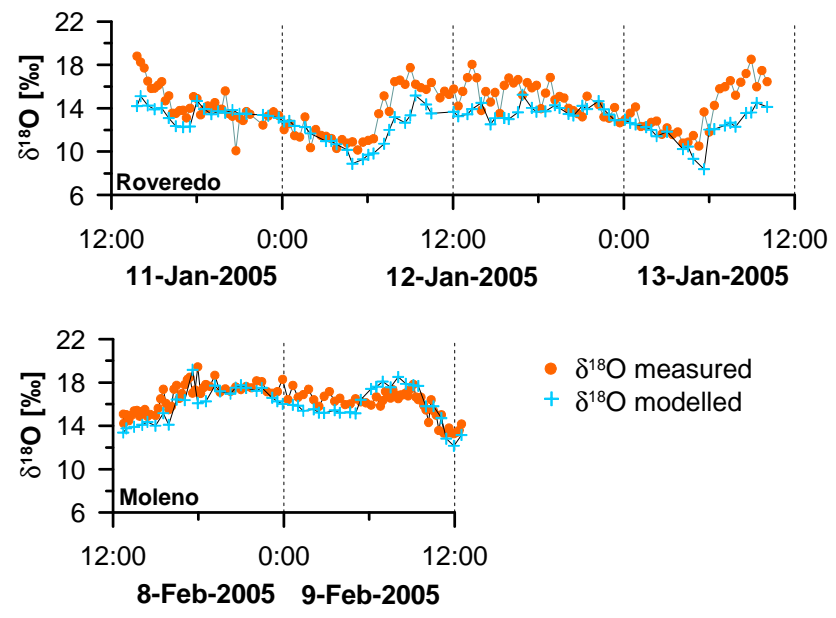

Fig. 9. Comparison of calculated and measured $\delta^{18} \mathrm{O}$ (model based on the combination of $\mathrm{CO} / \mathrm{NO}_{\mathrm{x}}$-separation and isotope mass balance, Eq. 15).

the isotope value of $\mathrm{CO}$ from wood combustion from $8-20 \%$ and the background isotope composition from 1-9\%, setting the traffic isotope value to either $20 \%$ or $23.88 \%$ o (the lower value derived from Kato et al. (1999b) for an average traffic mix). As indicators of the performance of the model, we used the correlation coefficient between modelled and measured values $(r)$, the slope of this correlation and the difference (offset) between model and data (expressed as square root of the sum of the squared differences). Obviously, the first two parameters should be as high as possible, while the latter one should be as low as possible for best model performance. It can be seen in Fig. 10a-c (i.e. for $\delta^{18} \mathrm{O}_{\text {traffic }}=23.88 \%$ o) that $r$ is highest for relatively low $\delta^{18} \mathrm{O}_{\mathrm{wb}}(10-14 \%)$, while the offset is lowest for high $\delta^{18} \mathrm{O}_{\mathrm{wb}}(16-20 \%)$, which makes it difficult to find the optimum $\delta^{18} \mathrm{O}_{\mathrm{wb}}$. This holds for all $\delta^{18} \mathrm{O}_{\mathrm{bgd}}$, but the mismatch between the optima regarding $r$ and the offset is lowest for relatively high $\delta^{18} \mathrm{O}_{\mathrm{bgd}}$. The slope criterion, however, indicates that too high values for $\delta^{18} \mathrm{O}_{\text {bgd }}$ are not appropriate, because then the slope would be too low. The slope would be highest for high $\delta^{18} \mathrm{O}_{\mathrm{wb}}$. Overall, it therefore seems that the values used so far (from literature and the wood-stove experiment) are close to optimum, because it is not possible to improve both $r$ and the offset by changing $\delta^{18} \mathrm{O}_{\mathrm{wb}}$, while changing $\delta^{18} \mathrm{O}_{\mathrm{bgd}}$ would either increase the offset (when decreasing $\delta^{18} \mathrm{O}_{\mathrm{bgd}}$ ) or decrease the slope (when increasing $\delta^{18} \mathrm{O}_{\text {bgd }}$ ). The same analysis for $\delta^{18} \mathrm{O}_{\text {traffic }}=20 \%$ o (Fig. 10d-f) shows slightly lower values for $r$ and the slope, independent from the values of the other sources, indicating lower model performance.

\subsection{Rural site (PSI)}

For a better assessment of diurnal cycles and the influence of meteorological conditions on the isotope variations of $\mathrm{CO}$, an 18-day period was analysed at a rural site (PSI) during winter 

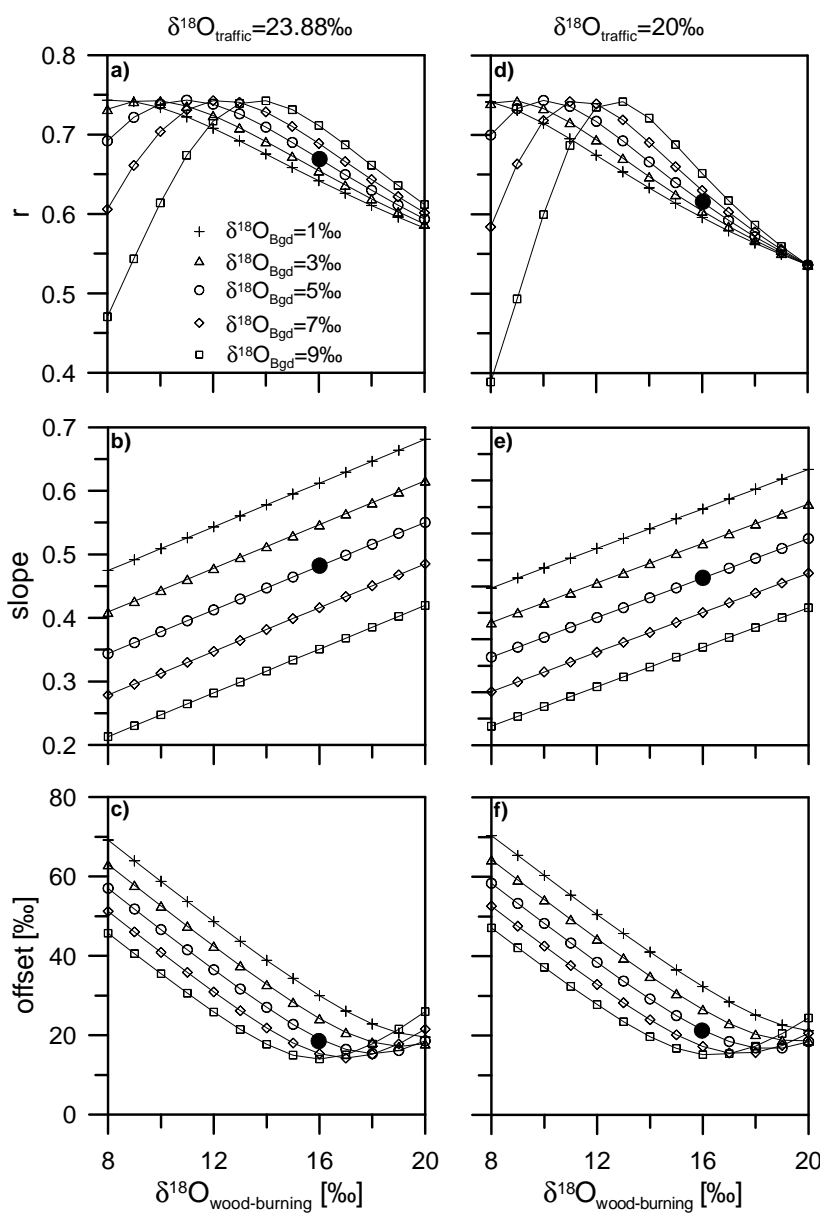

Fig. 10. Sensitivity analysis of the combined $\mathrm{CO} / \mathrm{NO}_{\mathrm{x}}$-isotope model (Eq. 15). The model performance is given as a function of the assumed values of $\delta^{18} \mathrm{O}$ of wood combustion, showing the correlation coefficient for the regression between measured and modelled values $(r)$, the slope and the offset between measurements and model (square root of sum of squared differences). Different lines in each panel refer to different values for the $\delta^{18} \mathrm{O}$ of the background. The black dot indicates the values used as the base case scenario. Figure a-c refer to $\delta^{18} \mathrm{O}_{\text {traffic }}=23.88 \%$ and Fig. $\mathrm{d}-\mathrm{f}$ to $\delta^{18} \mathrm{O}_{\text {traffic }}=20 \%$.

2006. The investigated period was characterized by dry and cold conditions, with temperatures mostly around or below the freezing point (Fig. 11). Precipitation only occurred two times (on 8 and 16 February), both times associated with a drop in air pressure and increase in temperature, indicating the passage of a warm front. Further, a drop in the $\mathrm{CO}$ concentration $\mathrm{c}(\mathrm{CO})$ as well as the $\delta^{18} \mathrm{O}$ of $\mathrm{CO}$ was observed, more strongly in the second event (Fig. 11). While the change in pressure was a gradual one occurring over several hours, the $\mathrm{CO}$ drop was almost instantaneous at the passage of the front, which obviously removed the local pollution and replaced it with relatively clean air. Over the whole 18-day period, $\delta^{18} \mathrm{O}$-values of $\mathrm{CO}$ closely followed the course of
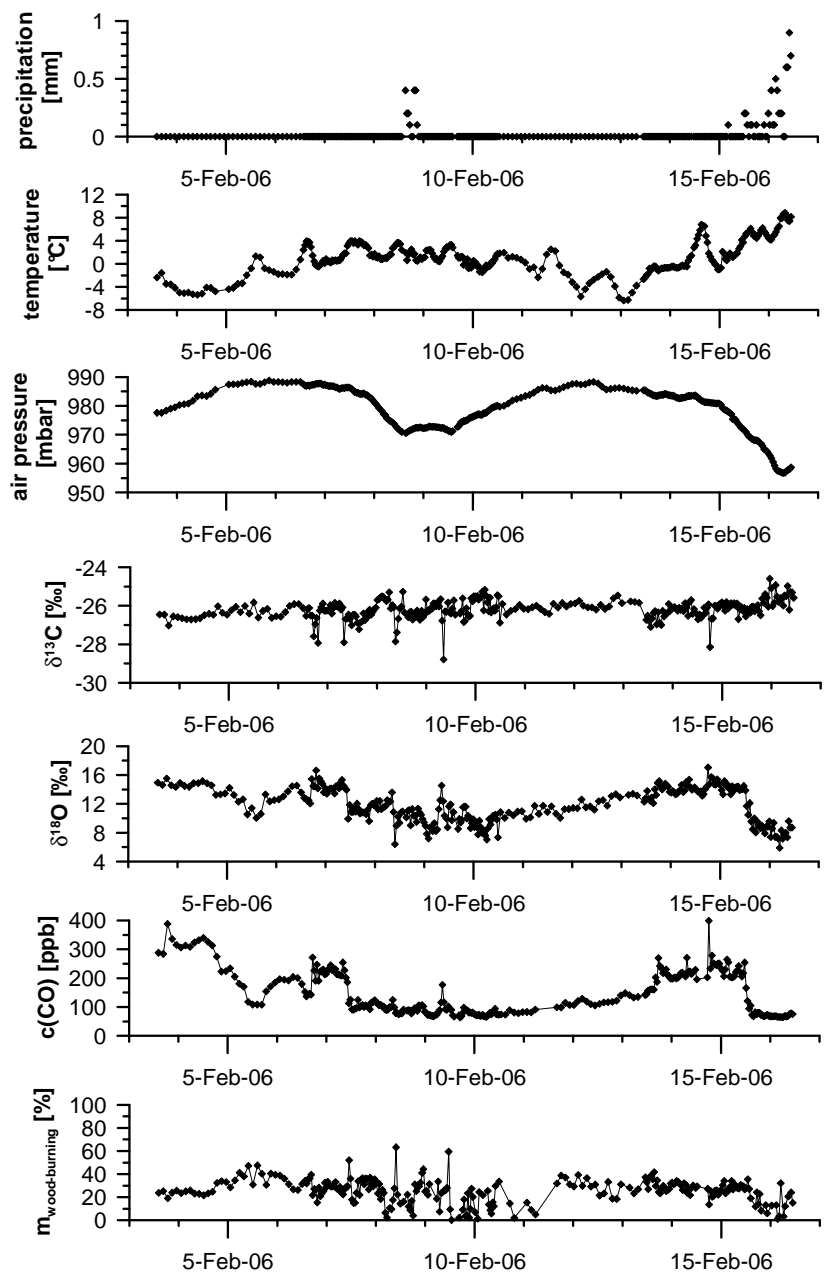

Fig. 11. Meteorological parameters, concentration and isotope ratios of $\mathrm{CO}$, and calculated contribution of wood-combustion to $\mathrm{CO}$ according to the isotope separation model (Eq. 8) over a period of 18 days in winter at a rural site (PSI).

Table 3. Correlation coefficients $(r)$ between meteorological conditions and the isotope ratios of $\mathrm{CO}$ for the rural site PSI. Correlations for the hour of the day are also shown. Bold numbers are significant according to t-test $(p<0.001)$.

\begin{tabular}{lrr}
\hline & ${ }^{13} \mathrm{C}[\% \mathrm{o}]$ & $\delta^{18} \mathrm{O}[\% \mathrm{o}]$ \\
\hline Hour GMT & -0.16 & 0.07 \\
Wind direction (DEG) & 0.04 & -0.13 \\
Wind speed (m/s) & $\mathbf{0 . 2 7}$ & $-\mathbf{0 . 6 8}$ \\
Wind speed N-S component (m/s) & 0.12 & $\mathbf{- 0 . 5 8}$ \\
Windspeed E-W component (m/s) & $\mathbf{0 . 2 4}$ & $\mathbf{- 0 . 5 5}$ \\
Air pressure (mbar) & $\mathbf{- 0 . 3 0}$ & $\mathbf{0 . 6 1}$ \\
Temperature $\left({ }^{\circ} \mathrm{C}\right)$ & 0.09 & $\mathbf{- 0 . 4 2}$ \\
Rainfall $(\mathrm{MM})$ & 0.17 & $\mathbf{- 0 . 3 1}$ \\
\hline
\end{tabular}


$\mathrm{c}(\mathrm{CO})$. Between the first and the second rain event, $\mathrm{c}(\mathrm{CO})$ as well as $\delta^{18} \mathrm{O}$ of $\mathrm{CO}$ increased slowly due to accumulation of pollutants in the inversion layer. The Keeling-plot revealed a tight linear relationship between $1 / \mathrm{c}(\mathrm{CO})$ and $\delta^{18} \mathrm{O}$ for this site with $r^{2}=0.88$ for day values and $r^{2}=0.92$ for night values, while the y-intercept was relatively low (17.48\%o and $17.47 \%$ o for day and night, respectively), see Fig. 5. The carbon isotope ratio of $\mathrm{CO}$ did not change during the rain events and did not show systematic longer-term variations either, but rather seemed to be influenced by small local disturbances. There is a significant negative correlation between $\mathrm{c}(\mathrm{CO})$ and $\delta^{13} \mathrm{C}(r=-0.37)$, which is much weaker, however, than the respective correlation for $\delta^{18} \mathrm{O}(r=0.88)$.

There are no clear diurnal cycles observed for $\delta^{13} \mathrm{C}$ and $\delta^{18} \mathrm{O}$ of CO at the rural site PSI and accordingly there is no correlation between the hour of day and the isotope signals (Fig. 11, Table 3). A correlation analysis with meteorological conditions showed that wind speed and air pressure can best explain the $\delta^{18} \mathrm{O}$ variations (Table 3 ). The same analysis for $\delta^{13} \mathrm{C}$ also showed a significant influence of these meteorological parameters. Further, the passage of weather fronts (represented by temperature and rainfall) had a strong impact on $\delta^{18} \mathrm{O}$.

We applied the isotope separation model (Eq. 8) to the PSI data, assigning the exact same $\delta^{18} \mathrm{O}$ values for the pure sources (referring to the base case above, $\delta_{\text {bgd }}=5 \%$; $\delta_{\mathrm{wb}}=16.3 \%$; $\delta_{\mathrm{t}}=23.88 \%$ o $)$ and further using $55 \mathrm{ppb}$ as background $\mathrm{CO}$ concentration. On average, we found a contribution of wood burning $\mathrm{m}_{\mathrm{wb}}$ to total CO of $23.7 \%(1 \sigma=12.0 \%)$, with no clear trends over the investigated period, but relatively high variability during low $\mathrm{CO}$ concentration periods (Fig. 11, Table 1). Interestingly, some anomalously high $\mathrm{m}_{\mathrm{wb}}$ values appear to be related to low $\delta^{13} \mathrm{C}$ values the reason for which is unknown. Diurnal cycles in calculated $\mathrm{m}_{\mathrm{wb}}$ are $\mathrm{ab}-$ sent, except maybe for 7 to 10 February. The $\mathrm{CO} / \mathrm{NO}_{\mathrm{x}}$ separation model could not be applied at the PSI site, unfortunately, due to the lack of $\mathrm{NO}_{\mathrm{x}}$ measurements.

\section{Discussion and conclusions}

For a successful source apportionment with stable isotopes of $\mathrm{CO}$, it is necessary to carefully characterize the isotopic signatures of the pure emissions. Regarding wood burning, the value of $16.3 \%$ obtained in our wood-stove experiment agrees very well with other estimates in the literature, namely $18 \% \circ \pm 1 \%$ (Stevens and Wagner, 1989) and $16.3 \%$ (Gros et al., 2002). In a controlled wood burning experiment, a larger range of values was reported, with low values down to $10 \%$ o for the smoldering phase, but the set-up used may be more representative for open fires (Kato et al., 1999b). This study indicated that under poor combustion conditions (e.g. low temperature or low oxygen), when the highest $\mathrm{CO}$ emissions occur, the highest isotope fractionation is involved resulting in the lowest $\delta^{18} \mathrm{O}$ values. Regarding traffic $\mathrm{CO}$ emissions, values could be close to the value of atmospheric $\mathrm{O}_{2}$ under ideal combustion conditions (hot engine) and in the absence of fractionations. A range of values was, however, reported for car emissions, where fuel type (Kato et al., 1999) and the use of catalysts (Huff and Thiemens, 1998) showed to have an impact on the $\delta^{18} \mathrm{O}$ of the emitted CO. In particular, diesel emissions were reported to produce significantly lower values than the atmospheric value of about $23.88 \%$ o. Depending on the car mix and the relative number of trucks, variable source values are to be expected. Kato et al. (1999a) observed an average source value of $20.7 \% \circ \pm 0.5 \%$ o for Mainz, Germany, sampled over an annual course and estimated the contribution of diesel exhaust to total CO as $14 \%$. Based on the above numbers, the difference between the wood-burning and the traffic signal could be as low as $20.7-18.3=2.4 \%$ or as high as $23.88 \% 0-10 \% o=13.88 \%$, but nevertheless appears to be significant under all scenarios. Regarding uncertainties with sources, it should also be noted that other sources than wood burning and traffic could have an influence, like industrial emissions, although these are probably of minor importance at the sites studies here. For $\delta^{13} \mathrm{C}$, the difference between the biomass burning and fossil fuel combustion signal is clearly smaller. Car emissions are expected to be isotopically lighter than the value of $-24.7 \%$ found in our assessment of the wood stove emissions, possibly by about $1-4 \%$ o (Widory et al., 2004). This small difference is a drawback for the successful use of carbon isotopes in source apportionment, which is also confirmed by the small variability of $\delta^{13} \mathrm{C}$ observed in our study.

Oxygen isotope values of $\mathrm{CO}$ at the village site Roveredo observed during the day in winter were much higher, when traffic was more frequent, compared to the evening and the night, when heating emissions dominated, reflecting the difference between the two sources. Other indicators of wood burning showed similar diurnal courses, namely the $\mathrm{CO} / \mathrm{NO}_{\mathrm{x}}$ concentration ratios and light absorption coefficients of aerosols collected on filters. The latter data in the low UV-range are known to be correlated to wood burning signature as organic compounds in wood smoke aerosols result in a strong UV absorption. Recent investigations also show a strong correlation between the absorption coefficients and ${ }^{14} \mathrm{C}$ data of carbonaceous aerosols collected during the same period and therefore enabled a quantitative calibration of the aethalometer data (Sandradewi et al., 2008a). ${ }^{14} \mathrm{C}$ is related to the ratio of fossil to non fossil sources and therefore depends to a large degree on the ratio of wood burning to traffic (Szidat et al., 2007). The radiocarbon data showed that the carbonaceous particles during the evening in winter in Roveredo originate to a major part from wood combustion, up to $90 \%$ during the night. Similar estimates for particulate matter originating from wood burning were obtained by the aethalometer model. The significant correlation between $\delta^{18} \mathrm{O}$ of $\mathrm{CO}$ and $\mathrm{PM}_{\mathrm{wb}} / \mathrm{PM}_{\text {total }}$ indicates an influence of wood burning for all these parameters. 
By high-resolution sampling, a very pronounced diurnal cycle in $\delta^{18} \mathrm{O}$ of $\mathrm{CO}$ (not in $\delta^{13} \mathrm{C}$ ) could be detected. The diurnal variations are, however, not only caused by variations in the sources, but also by turbulence and convection and mixing with clean, background air from higher levels of the atmosphere. The diurnal pattern is strongly enhanced by the alternating occurrence of static and turbulent conditions typical for valleys (Prévôt et al., 2000a). This is similar for the two polluted sites studied, even when the dilution occurs by downwind-slopes at night in Roveredo, or by convection during the day in Moleno. These results are in strong contrast with a prolonged series of measurements done in flat terrain at a rural location. First, the source strength is smaller for this site. The emissions are farther away and have more time to mix. Weaker inversions over the flatter terrain also allow longer transport distances and thus mixing of source regions compared to the valley. The sites in the valley are thus more affected by close pollution sources and subject to a higher range of $\mathrm{c}(\mathrm{CO})(300-1500 \mathrm{ppb})$ compared to the rural site (70 to $400 \mathrm{ppb}$ ), and second there is not this distinct alternating pattern of static and turbulent conditions when a typical wintertime stratus cloud deck is covering the flat terrain in Switzerland. Accordingly, no significant diurnal signal in $\delta^{18} \mathrm{O}$ of $\mathrm{CO}$ was observed on flat terrain at the site PSI, but a strong influence of the synoptic weather patterns, reflected in the high correlations to wind speed and atmospheric pressure (Table 3). This again emphasizes the important influence of background air compared to local conditions. This holds in particular, as $\mathrm{CO}$ in background air with increasing age of the air masses is affected by fractionation processes that result in a very low ${ }^{18} \mathrm{O}$-content (Brenninkmeijer et al., 1999).

For a quantitative analysis including the effect of the admixture of background air, a Keeling-plot approach is often useful. This calculation, however, is based on the assumption of a two end-member mixing model (Eqs. 3-5). In fact, there is no strong relationship observed between $\delta^{18} \mathrm{O}$ and $1 / \mathrm{c}(\mathrm{CO})$ for both Roveredo and Moleno, in particular during the night. The correlation coefficients are lower than in other published studies (Brenninkmeijer et al., 1999), reflecting the fact that there are more than two components to be considered at the studied sites. As we have shown, there are large diurnal variations in the contribution of woodburning and traffic to the CO load and accordingly there does not exist a unique y-intercept, i.e. source isotope signal, which results in the scatter observed in Fig. 5. The yintercepts therefore have to be interpreted with caution. They are lower during the night, indicating the increased influence of wood-burning. At the traffic-dominated site Moleno, the $\mathrm{y}$-intercept during the day is highest $(18.9 \%$ ), but still far from the "ideal" traffic value of $23.88 \%$ o. This is due to the influence of still some wood-burning emissions at this location, and probably also a value for pure traffic emissions closer to about $20 \%$ as determined by Kato et al. (1999b). The conditions at the study site are apparently not ideal for applying the Keeling-plot calculation. Another uncertainty that cannot completely be ruled out is the influence of variations in the background isotopic composition. For the rural site PSI, we observed a much stronger relationship between $1 / \mathrm{c}(\mathrm{CO})$ and $\delta^{18} \mathrm{O}\left(r^{2}=0.88-0.92\right)$, but no significant difference between day and night Keeling plots. The closer relationship of the two parameters compared to Roveredo and Moleno indicates less variability in the pollution mix reaching this site, which is reasonable considering that it is farther away from direct sources. Still the interpretation of the y-intercepts in the order of $17.5 \%$ is not straightforward, as this value reflects the mixture of pollutants reaching PSI. The value is in between the wood-burning-dominated night-time value of Roveredo $(15.0 \%)$ and the traffic-dominated day-time value of Moleno $(18.9 \%$ ) , probably showing also a mixture of the two at this less polluted site.

Solving the isotope mass balance equation with 3 source terms for the wood burning contribution to $\mathrm{CO}$ for Roveredo and Moleno (Fig. 6) resulted in a plausible diurnal pattern of traffic dominated emissions during the day and wood burning dominated emissions during the night. However, a strong sensitivity of the model result to the input parameters was also apparent. For the base case scenario, we inferred a $\mathrm{m}_{\mathrm{wb}}$ of $60-80 \%$ for Roveredo and 40-60\% for Moleno during night. Nevertheless, a quantitative analysis is still hampered by the incomplete knowledge of the source isotope values. We found that changes of only a few permil in the assumed source isotope values may easily result in changes of 20 or more percent in the calculated $\mathrm{m}_{\mathrm{wb}}$. We investigated a range of values for the three different sources and could to some degree constrain possible source isotope values with the aid of the simple criterion that $\mathrm{m}_{\mathrm{wb}}$ should not be smaller than $0 \%$ and not larger than $100 \%$ during any time of the investigated period. In this way, we could show that $\delta_{\text {bgd }}$ should be close to $5 \%$, while $\delta_{t}$ could not clearly be discriminated between $20 \%$ and $23.88 \%$.

For an independent evaluation of this result and to more clearly constrain the isotope budget, we additionally considered the $\mathrm{CO} / \mathrm{NO}_{\mathrm{x}}$ concentration ratio. The gas phase concentrations $\mathrm{c}(\mathrm{CO})$ and $\mathrm{c}\left(\mathrm{NO}_{\mathrm{x}}\right)$ are rather simple to measure and are routinely monitored at many stations for air quality control. However, there is a similar problem as above in that the "pure" $\mathrm{CO} / \mathrm{NO}_{\mathrm{x}}$ emission ratios for wood burning and for traffic are not very well confined or may be variable over time. We approached this problem by a detailed analysis of $\mathrm{CO} / \mathrm{NO}_{\mathrm{x}}$ concentration ratios at different times of the day, assigning the highest values to wood-emissions and the lowest values to traffic emissions. The calculated $\mathrm{m}_{\mathrm{wb}}$ with this model agrees remarkably well with the independent estimation based on the isotope source separation model (Fig. 6). The two models yield similar diurnal patterns for Roveredo and Moleno and similar maximum night-time contributions of about $70-80 \%$ in Roverdo and $50-60 \%$ in Moleno. Results from ${ }^{14} \mathrm{C}$ measurements indicated even higher contributions of non-fossil derived carbonaceaous aerosols in the evening, which could be due to higher emission ratios of 
wood burning to traffic for carbonaceous aerosols compared to CO (Szidat et al., 2007). The surprisingly high contribution of non-fossil carbonaceous aerosol in Moleno was explained by the influence of heating sources in the surrounding villages. At a rural site (PSI), we observed much lower wood burning contributions (20-30\%) to $\mathrm{CO}-$ a result that was expected because wood-heating in this area is not known as very significant. Still, these findings confirm that wood burning emissions during winter may be a much more widespread phenomenon in industrialized regions than previously assumed. In Zurich, a city approximately $30 \mathrm{~km}$ distant from the PSI site, biomass burning emissions were estimated to contribute between $25 \%$ and $40 \%$ to the total carbonaceous aerosol load in winter (Szidat et al., 2006; Lanz et al., 2008), similar to the value of $20-30 \%$ inferred here for $\mathrm{CO}$ at the rural site.

Finally, with the $\mathrm{CO} / \mathrm{NO}_{\mathrm{x}}$ isotope model (Eq. 15), we applied a novel combination of isotope and gas phase measurements to tackle the problem that the source isotope values are not known very precisely. This combined model performed well on the "best estimates" (base case) for the pure isotope source values, for two different sites with different pollution mixtures and different advection of clean background air. The strengths of the approach are twofold: (1) It confirms indirectly the usefulness of the $\mathrm{CO} / \mathrm{NO}_{\mathrm{x}}$ split model (Eqs. 9-14), because it would not work on two such different sites as Roveredo and Moleno if the emission ratios would not be appropriate. By including the isotope part, it is therefore possible to confirm the split-model (assuming here that the isotope source values are appropriate). The $\mathrm{CO} / \mathrm{NO}_{\mathrm{x}}$ split model can then be applied to much larger datasets and other stations because these data are widely available (2) Testing the isotope source values is possible by a sensitivity analysis (Fig. 10). This test indicated that our best estimate values are actually close to optimum, because changing the source values would either reduce the correlation coefficient between measurements and calculations or would result in an offset between the two. These two applications of the model are not independent from each other as the first assumes knowledge of the source isotope values to test the $\mathrm{CO} / \mathrm{NO}_{\mathrm{x}}$-split model, while the second assumes the $\mathrm{CO} / \mathrm{NO}_{\mathrm{x}}$-split model to be correct for testing variations of the isotope source values. The good agreement between model and measurements in Fig. 9 is a strong indication for the usefulness of the combined model, but we would consider it a proof of concept rather than a strict validation. More studies with better definition of the source isotope values would clearly be helpful to verify the approach. This could be done with the help of Keeling-plot analyses in situations where one pollutant dominates. Once the source values are better characterized the isotope mass balance equation may be more widely applied. We think that the CO/NOx model and the isotope mass balance are complementary and confirm each other in a situation where there are uncertainties in both.
Acknowledgements. We thank Jan Eitel for support during field measurements and M. Mohr and D. Schreiber (EMPA, Dübendorf, Switzerland) for providing access to the wood stove experiment at the test facility of EMPA. We thank the Office of Nature and Environment of Canton Graubünden for providing data from the monitoring stations and the Swiss Federal Office for the Environment (FOEN) for funding the AEROWOOD project.

Edited by: J. Kaiser

\section{References}

Alfarra, M. R., Prévôt, A. S. H., Szidat, S., Sandradewi, J., Weimer, S., Lanz, V. A., Schreiber, D., Mohr, M., and Baltensperger, U.: Identification of the mass spectral signature of organic aerosols from wood burning emissions, Environ. Sci. Technol., 41, 57705777, 2007.

Barkan, E. and B. Luz: High precision measurements of ${ }^{17} \mathrm{O} /{ }^{16} \mathrm{O}$ and ${ }^{18} \mathrm{O} /{ }^{16} \mathrm{O}$ ratios in $\mathrm{H}_{2} \mathrm{O}$, Rapid Comm. Mass Spectrom., 19(24), 3737-3742, 2005.

Brenninkmeijer, C. A. M., Röckmann, T., Bräunlich, M., Jöckel, P., and Bergamaschi, P.: Review of progress in isotope studies of atmospheric carbon monoxide, Chemosphere, 1, 33-52, 1999.

Crutzen, P. J. and Zimmermann, P. H.: The changing photochemistry of the troposphere, Tellus, 43, 136-151, 1991.

Dommen, J., Prévôt, A. S. H., Neininger, B., and Bäumle, M.: Characterization of the photooxidant formation in the metropolitan area of Milan from aircraft measurements, J. Geophys. Res., 107, 8197, doi:8110.1029/2000JD000283, 2002.

Gaeggeler, K., Prévôt, A. S. H., Dommen, J., Legreid, G., Reimann, S., and Baltensperger, U.: Residential wood burning in an Alpine valley as a source for oxygenated volatile organic compounds, hydrocarbons and organic acids, Atmos. Environ., 42, 82788287, doi:10.1016/j.atmosenv.2008.07.038, 2008

Gros, V., Jöckel, P., Brenninkmeijer, C. A. M., Röckmann, T., Meinhardt, F., and Graul, R.: Characterization of pollution events observed at Schauinsland, Germany, using CO and its stable isotopes, Atmos. Environ., 36, 2831-2840, 2002.

Huff, A. K. and Thiemens, M. H.: ${ }^{17} \mathrm{O} /{ }^{16} \mathrm{O}$ and ${ }^{18} \mathrm{O} /{ }^{16} \mathrm{O}$ isotope measurements of atmospheric carbon monoxide and its sources, Geophys. Res. Lett., 25, 3509-3512, 1998.

Jeong, C.-H., Hopke, P. K., Kim, E., and Lee, D.-W.: The comparison between thermal-optical transmittance elemental carbon and Aethalometer black carbon measured at multiple monitoring sites, Atmos. Environ., 38, 5193-5204, 2004.

Johansson, L. S., Leckner, B., Gustavsson, L., Cooper, D., Tullin, C., and Potter, A.: Emission characteristics of modern and oldtype residential boilers fired with wood logs and wood pellets, Atmos. Environ., 38, 4183-4195, 2004.

Kato, S., Akimoto, H., Bräunlich, M., Röckmann, T., and Brenninkmeijer, C. A. M.: Measurements of stable carbon and oxygen isotopic compositions of CO in automobile exhausts and ambient air from semi-urban Mainz, Germany, Geochem. J., 33, 7377, 1999a.

Kato, S., Akimoto, H., Röckmann, T., Bräunlich, M., and Brenninkmeijer, C. A. M.: Stable isotopic compositions of carbon monoxide from biomass burning experiments, Atmos. Environ., 33, 4357-4362, $1999 \mathrm{~b}$. 
Kirchstetter, T. W., Harley, R. A., Kreisberg, N. M., Stolzenburg, M. R., and Hering, S. V.: On-road measurement of fine particle and nitrogen oxide emissions from light- and heavy-duty motor vehicles Atmos. Environ., 33, 2955-2968, 1999.

Lanz, V. A., Alfarra, M. R., Baltensperger, U., Buchmann, B., Hueglin, C., and Prévôt, A. S. H.: Source apportionment of submicron organic aerosols at an urban site by factor analytical modelling of aerosol mass spectra, Atmos. Chem. Phys., 7, 15031522, 2007,

http://www.atmos-chem-phys.net/7/1503/2007/.

Lanz, V. A., Alfarra, M. R., Baltensperger, U., Buchmann, B., Hueglin, C., Szidat, S., Wehrli, M. N., Wacker, L., Weimer, S., Caseiro, A., Puxbaum, H., and Prévôt, A. S. H.: Source attribution of submicron organic aerosols during wintertime inversions by advanced factor analysis of aerosol mass spectra, Environ. Sci. Technol., 42, 214-220, 2008.

Mak, J. E. and Yang, W. B.: Technique for analysis of air samples for ${ }^{13} \mathrm{C}$ and ${ }^{18} \mathrm{O}$ in carbon monoxide via continuous-flow isotope ratio mass spectrometry, Anal. Chem., 70, 5159-5161, 1998.

Pataki, D. E., Ehleringer, J. R., Flanagan, L. B., Yakir, D., Bowling, D. R., Still, C. J., Buchmann, N., Kaplan, J. O., and Berry, J. A.: The application and interpretation of Keeling plots in terrestrial carbon cycle research, Global Biogeochem. Cy., 1022, doi:10.1029/2001GB001850, 2003.

Prévôt, A. S. H., Dommen, J., and Bäumle, M.: Influence of road traffic on volatile organic compound concentrations in and above a deep Alpine valley, Atmos. Environ., 34, 4719-4726, 2000a.

Prévôt, A. S. H., Dommen, J., Bäumle, M., and Furger, M.: Diurnal Variations of volatile organic compounds and local circulation systems in an Alpine valley, Atmos. Environ., 34, 1413-1423, 2000b.

Röckmann, T., Jöckel, P., Gros, V., Bräunlich, M., Possnert, G., and Brenninkmeijer, C. A. M.: Using ${ }^{14} \mathrm{C},{ }^{13} \mathrm{C},{ }^{18} \mathrm{O}$ and ${ }^{17} \mathrm{O}$ isotopic variations to provide insights into the high northern latitude surface CO inventory, Atmos. Chem. Phys., 2, 147-159, 2002, http://www.atmos-chem-phys.net/2/147/2002/.

Sandradewi, J., Prévôt, A. S. H., Szidat, S., Perron, N., Alfarra, M. R., Lanz, V. A., Weingartner, E., and Baltensperger, U.: Using aerosol light absorption measurements for the quantitative determination of wood burning and traffic emission contributions to particulate matter, Environ. Sci. Technol., 42, 3316-3323, 2008a.

Sandradewi, J., Prévôt, A. S. H., Weingartner, E., Schmidhauser, R., Gysel, M., and Baltensperger, U.: A study of wood burning and traffic aerosols in an Alpine valley using a multi-wavelength Aethalometer, Atmos. Environ., 42, 101-112, doi:110.1016/j.atmosenv.2007.1009.1034, 2008b.
Saurer, M., Robertson, I., Siegwolf, R., and Leuenberger, M.: Oxygen isotope analysis of cellulose: An interlaboratory comparison, Anal. Chem., 70, 2074-2080, 1998.

Steinbacher, M., Zellweger, C., Schwarzenbach, B., Bugmann, S., Buchmann, B., Ordonez, C., Prévôt, A. S. H., and Hueglin, C.: Nitrogen oxide measurements at rural sites in Switzerland: Bias of conventional measurement techniques, J. Geophys. Res., 112, D11307, doi:10.1029/2006JD007971, 2007.

Stevens, C. M., Walling, D., Venters, A., Ross, L. E., Engelkem, A, and Krout, L.: Isotopic composition of atmospheric carbon monoxide, Earth. Planet. Sc. Lett., 16, 147-165, 1972.

Stevens, C. M. and Wagner, A. F.: The role of isotope fractionation effects in atmospheric chemistry, Z. Naturforsch., 44A, 376-384, 1989.

Szidat, S., Jenk, T. M., Synal, H.-A., Kalberer, M., Wacker, L., Hajdas, I., Kasper-Giebl, A., and Baltensperger, U.: Contribution of fossil fuel, biomass-burning, and biogenic emissions to carbonaceous aerosols in Zurich as traced by ${ }^{14} \mathrm{C}$, J. Geophys. Res., 111, D07206, doi:10.1029/2005JD006590, 2006.

Szidat, S., Prévôt, A. S. H., Sandradewi, J., Alfarra, M. R., Synal, H. A., Wacker, L., and Baltensperger, U.: Dominant impact of residential wood burning on particulate matter in Alpine valleys during winter, Geophys. Res. Lett., 34, L05820, doi:10.1029/2006GL028325, 2007.

Theis, D. E., Saurer, M., Blum, H., Frossard, E., and Siegwolf, R. T. W.: A portable automated system for trace gas sampling in the field and stable isotope analysis in the laboratory, Rapid Commun. Mass Spectrom., 18, 2106-2112, 2004.

Tsunogai, U., Hachisu, Y., Komatsu, D. D., Nakagawa, F., Gamo, T., and Akiyama, K.: An updated estimation of the stable carbon and oxygen isotopic compositions of automobile $\mathrm{CO}$ emissions, Atmos. Environ., 37, 4901-4910, 2003.

Weimer, S., Alfarra, M. R., Schreiber, D., Mohr, M., Prévôt, A. S. H., and Baltensperger, U.: Organic aerosol mass spectral signatures from wood burning emissions: Influence of burning conditions and wood type, J. Geophys. Res., 113, D10304, doi:10.1029/2007JD009309, 2008.

Widory, D., Roy, S., Le Moullec, Y., Goupil, G., and Cocherie, A.: The origin of atmospheric particles in Paris: a view through carbon and lead isotopes, Atmos. Environ., 38, 953-961, 2004. 